\title{
Anthropogenic geomorphic change as a potential generator of renewable geologic resources in the humid Pampa of Argentina
}

\author{
Luis M. Forte ${ }^{\mathrm{a}, \mathrm{b}, *}$, Martín H. Hurtado ${ }^{\mathrm{a}, \mathrm{b}}$, Nauris V. Dangvas a ${ }^{\mathrm{a}}$, Luis Couyoupetrou ${ }^{\mathrm{a}, \mathrm{c}}$, Jorge E. Giménez ${ }^{\mathrm{a}}$, \\ Mario M. da Silva ${ }^{\mathrm{a}}$, Viola M. Bruschi ${ }^{\mathrm{b}}$, Antonio Cendrero ${ }^{\mathrm{a}, \mathrm{b}}$ \\ a Universidad Nacional de La Plata, Argentina \\ ${ }^{\mathrm{b}}$ Universidad de Cantabria, Santander, Spain \\ c Comisión de Investigaciones Científicas, Provincia de Buenos Aires, Argentina
}

\section{A R T I C L E I N F O}

\section{Article history:}

Received 28 July 2015

Received in revised form 2 February 2016

Accepted 8 February 2016

Available online 1 April 2016

\section{Keywords:}

Global geomorphic change

Soil mining

Soil erosion

Lake sediments

Brick industry

Anthropocene

\begin{abstract}
A B S T R A C T
The nature and amount of sediments in various lakes, intermittent swampy areas and river sectors in the humid Pampa (Buenos Aires Province, Argentina) were analysed. The aim was to determine whether recent sediments in such environments could serve as an alternative resource to the brick industry, for minimising the current, high environmental impact of soil mining. Sediment sequences were obtained, and the thicknesses of the upper sediment layers, corresponding to the suballuvial (approx. 1400-700 years BP) and alluvial (approx. 250 years BP to present) were determined. Sediment samples were collected and analysed for grain size and Atterberg limits. Suitable sediments were then selected to determine the optimal brick materials and their technical properties. Similarly, control bricks were prepared with ceramic pastes of local industries. The results show that the quality of the former is similar or superior to that of the latter. The initial estimates of the available resource indicate a long-term supply for the industry. Estimates of the current sedimentation rates indicate that resource renewal might occur at a rate comparable to current consumption. The sedimentation rates have increased significantly in the past two centuries - more so in the past few decades (the Anthropocene?) - with increasing human modification of geomorphic processes. If the results presented here are confirmed, a highly sustainable model can be implemented in the brick industry.
\end{abstract}

C 2016 Elsevier B.V. All rights reserved.

\section{Introduction}

A 'geomorphic dimension of global change' or a 'global geomorphic change' may be in place, as noted by researchers (Cendrero and Douglas, 1996; Rivas et al., 2006). These terms refer to changes in the rates of geomorphic processes due to human modifications of the land surface and not climate change. These changes are occurring at a global scale, typical of the Anthropocene, which affect the rates of geomorphic processes, and the frequency of related natural hazards (Cendrero et al., 2006; Bonachea et al., 2010; Forte, 2011; Bruschi et al., 2012a,b, 2013). Such geomorphic changes lead to direct, deliberate excavation and transport of rocks, sediments and soils and indirect, unintended erosion due to human activities that disturb the land surface. In general, human-induced geomorphic changes have led to increasing surface geologic processes, particularly after the middle of the 20th century, coinciding with the sharp increase in human activities and their effects known as the 'Great Acceleration' (Steffen et al., 2004, 2011, 2015). The Great Acceleration represents a 'great geomorphic acceleration'

\footnotetext{
* Corresponding author at: Universidad Nacional de La Plata, Argentina. E-mail address: lmforte@igs.edu.ar (L.M. Forte).
}

(Bruschi et al., 2013; Bruschi et al., 2012a,b; Hurtado et al., 2012), which can be problematic but beneficial as well.

The humid Pampas, in Argentina, is an interesting case study. This region is characterised by a significant 'human geomorphic footprint' (Rivas et al., 2006) due to soil mining for brick making. The Pampa is a loess-dominated plain with limited materials that are suitable for construction. Thus, brick construction has flourished here, with soil being used as a raw material. Since the 19th century, soil mining has been the main source of raw materials for brick making in the humid Pampa and other areas of Argentina (Del Río et al., 2001; Forte et al., 2004; Hurtado et al., 2008). At present, this activity is primarily responsible for the relief modification and sediment transport seen in the area, as well as the significant environmental degradation, particularly around urban centres (Giménez et al., 2002; Rivas et al., 2006; Hurtado, 2015). Similar effects of soil mining have been described across various parts of the world (Lal, 1997; Yadav, 2003; Singh and Asgher, 2005; Haack and Khatiwada, 2007; Zhang and Fang, 2007; Gupta and Narayan, 2010; Santhosh et al., 2013).

Increased sediment generation is highly prevalent worldwide (Judson, 1983; Kesel et al., 1992; Walling, 2000, 2006; Yang et al., 2004; Syvitski et al., 2005; Knox, 2006; Syvitski and Milliman, 2007; Wilkinson and McElroy, 2007; Syvitski and Kettner, 2011; Milliman 
and Farnsworth, 2011). Increasing sediment production and silting of lakes and ponds due to soil erosion in farmlands and sites affected by human-induced excavation/accumulation processes have been reported for various study areas (Hooke, 1994; Douglas, 1996; Ziegler et al., 2000; Phippen and Wohl, 2003; Gellis et al., 2004; Ramos-Scharrón and Mac Donald, 2005; Chin, 2006; Rivas et al., 2006; Carvalho et al., 2010). In the study region, several shallow lakes have been converted to 'bañados' (swampy areas covered with water for a short period annually) via sediment deposition. Thus, areas used for recreation and fishing are lost, and their natural flood-buffering capacity is reduced (Dangavs et al., 2006; Dangavs, 2008; Dangavs and Reynaldi, 2008; Dangavs, 2010). Thus, most of the sediment carried into the lakes originates from the erosion of the topsoil, the A and, to a lesser extent, B horizons, those used for brick making.

The aim of the present study was to assess alternative resources for brick making to minimise the environmental impacts related to soil mining. Thus, with suitable alternatives, two environmental degradation problems related to geomorphic change - land degradation caused by soil mining and floods - can be mitigated. Further, the soil mining activity in the region can be significantly reduced or eliminated altogether. The natural - although human-enhanced - erosion process can provide raw materials for the building industry sustainably, and the extraction of lake sediments can help maintain the depth and flood-buffering capacity of lakes.

In the ceramic industry, soil mining has been performed for a long time and remains a common practice in other parts of the world
(Mbumbia et al., 2000; Singh and Asgher, 2005; Zhang and Fang, 2007; Ngon Ngon et al., 2009; Nzeukou et al., 2013; Santhosh et al., 2013). The possibility of using sediments as raw materials for brick making has also been explored (Bhatnagarjm et al., 1994; Chiang et al., 2008; Samara et al., 2009; Mezencevova et al., 2012; Cappuyns et al., 2015). Various other raw materials may be explored with similar approaches to obtain results comparable to that of the present study.

\section{Study area}

\subsection{Main environmental characteristics}

The area selected for the study is a sector of the humid Pampa in the Buenos Aires Province, southeast (SE) of the Buenos Aires conurbation (Fig. 1). The region has a 250-1500-m-thick Miocene-Quaternary sedimentary cover, over a Paleozoic-Precambrian basement. The upper layer is composed of loess sediments of the Buenos Aires and Ensenada formations - the 'Pampeano', deposited between 700,000 and 10,000 years BP (Iriondo, 2010) - covered by aeolian and fluvial post-Pampean sediments (Fig. 1). The surface of these formations has been subject to successive erosion and deposition processes with the alternating dry and wet periods beginning approximately 10,000 years ago. Before the Little Ice Age (LIA), a wet period occurred around 1400-700 years BP. The lake sediments discussed in this study began to form during this period (Iriondo and García, 1993; Iriondo, 1999) and they continue to be deposited.

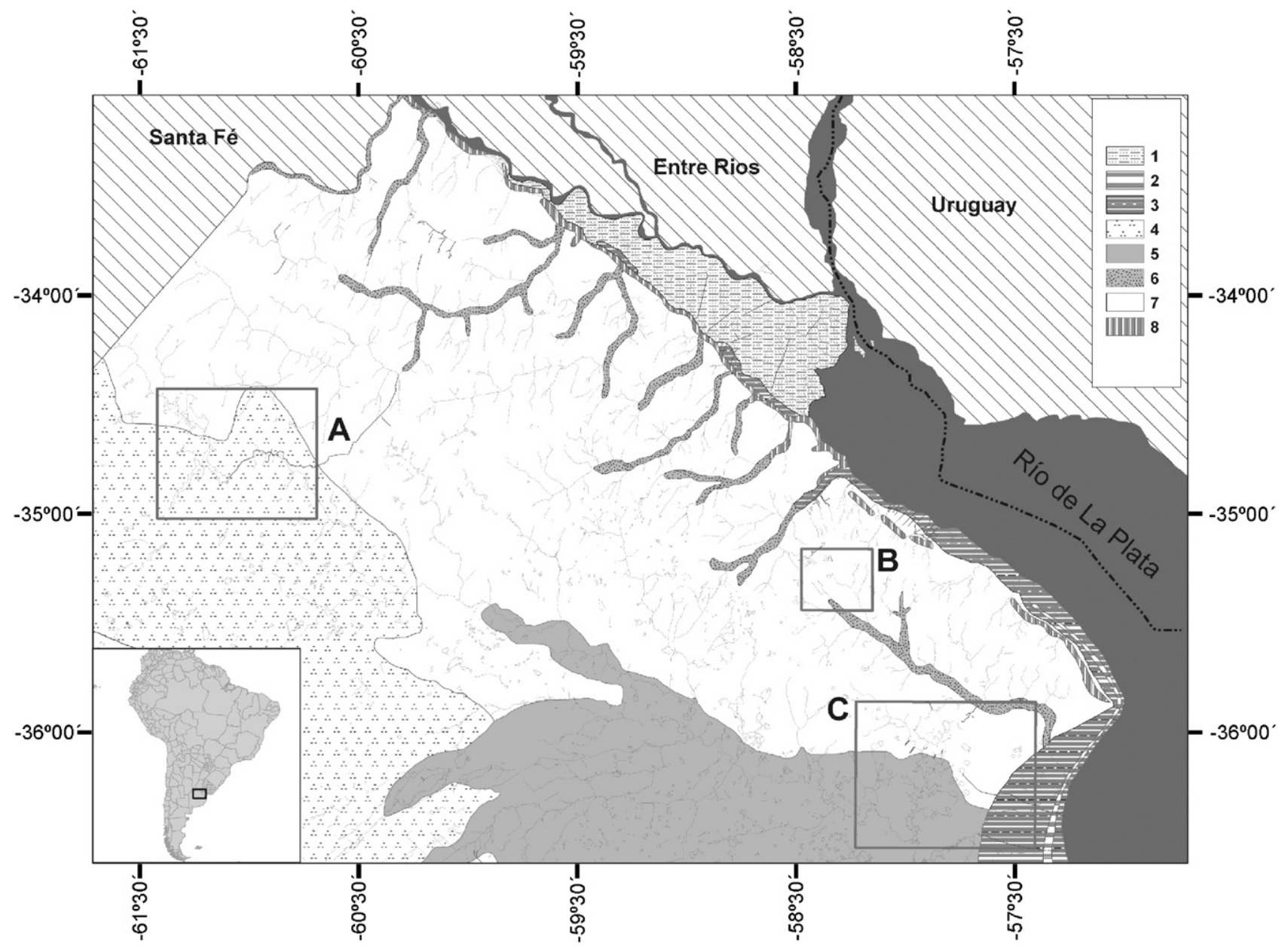

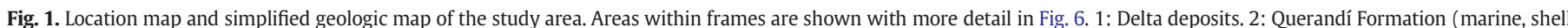

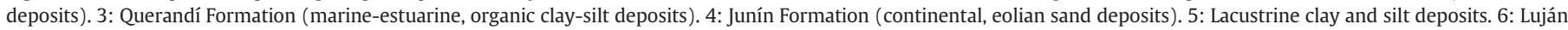

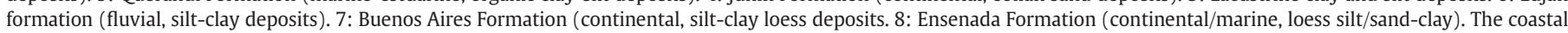
plain coincides essentially with the area occupied by the Querandí Formation. 
Two main environments can be identified (Frenguelli, 1950, Fidalgo and Martínez, 1983; Fidalgo et al., 1991; Cavallotto, 2002): (A) the coastal plain, a flat, swampy area, generally below an altitude of $5 \mathrm{~m}$, with marine and fluvio-estuarine deposits formed during late Pleistocene-Holocene transgressions and regressions, which alternate; and (B) the continental area, in which the upper formations are of fluvial and loess origin. The relief is extremely gentle, with maximum altitudes $<50 \mathrm{~m}$ and very low gradients, often $<0.5 \%$ and rarely $>2.0 \%$. Therefore, water frequently accumulates in several flat, poorly drained areas or blowout depressions present across this area (Fig. A; supplementary information). The lakes and deposits studied here are located in the continental area, as are the majority of soil mining operations. Soils in this unit are mainly typic and vertic argiudols, thapto-argic hapludols and typic hapluderts.

The humid Pampa contains several thousand lakes and wetlands of varying types and sizes (Fig. A; supplementary information). They represent a valuable environmental resource, for example, for sports and commercial fishing, reed harvesting, hunting, recreation and tourism and regulation of the water cycle during flooding. According to Dangavs (2005), the Buenos Aires Province has some 146,000 lakes over areas of $0.01-10$ ha, and approximately 10,500 lakes spanning $>10$ ha. The same author reported a total area of lakes within the province of $3175 \mathrm{~km}^{2}$. No detailed data on the number of 'bañados' and the area covered are available, although the unsystematic survey performed for this study revealed several of these. They are likely to cover a total area similar to lakes. Lakes and 'bañados' are likely to cover $4000-5000 \mathrm{~km}^{2}$, which is a very conservative estimate.

The climate is temperate humid, with annual rainfall ranging between 900 and $1200 \mathrm{~mm}$. The land cover and land use primarily comprise pasturelands and farmlands. The main crops include soy and various cereals. Horticulture and floriculture are key activities in certain areas surrounding cities. Urban land is also of importance, as the Buenos Aires conurbation comprises a population of approximately 13 million. Areas with more or less natural vegetation represent a very small proportion, which are essentially limited to a part of the margins along the Rio de la Plata estuary.

\subsection{Sedimentary sequence in lakes}

The typical sedimentary sequence of these lakes (Fig. 2) overlies the Buenos Aires and Ensenada formations (sandy silts; middle and upper Pleistocene, respectively). The first lake deposit is represented by Upper Pleistocene fluviolacustrine brown-grey sandy silts (Luján formation, La Chumbiada member; 3, in Fig. 2; Dillon and Rabassa, 1985 ), dating as far back as $>28,000$ years BP. The next level is composed of greenish clay pellets flocculated around fine sand grains (La Postrera I formation (4); Dangavs, 1979). It is considered to be formed via aeolian processes during a dry and cold period from 28,000 to 18,000 years BP. The top layer comprises green-yellow sandy silts and clays with epigenetic gypsum (Luján formation, Lobos member (5); Dangavs and Blasi, 2003). They were formed in brackish and freshwater environments, during a wetter and warmer period, between approximately 18,000 and 8500 years BP. In some locations, a new aeolian deposit, La Postrera II (6), overlies this layer. The next layer is composed of light-grey clayey sediments with abundant fossil remains of freshwater organisms and volcanic ash. This is the Rio Salado member of the Luján formation (Fidalgo et al., 1973), equivalent to the Platense of Ameghino (1884), attributed to a warm and wet period from 8500 to 3500 years BP.

Grey sandy clay and silt deposits appear over the former unit, but only in some lakes. These deposits correspond to the suballuvial (Doering, 1884) or Aimarense (Ameghino, 1889), attributed to a new wet and warm period, spanning 1400-700 years BP. In some cases, a brown-grey loess deposit is observed, which is affected by soilforming processes and is sometimes mixed with the above layer, attributed to the cold and dry period of the LIA, and the La Postrera IV

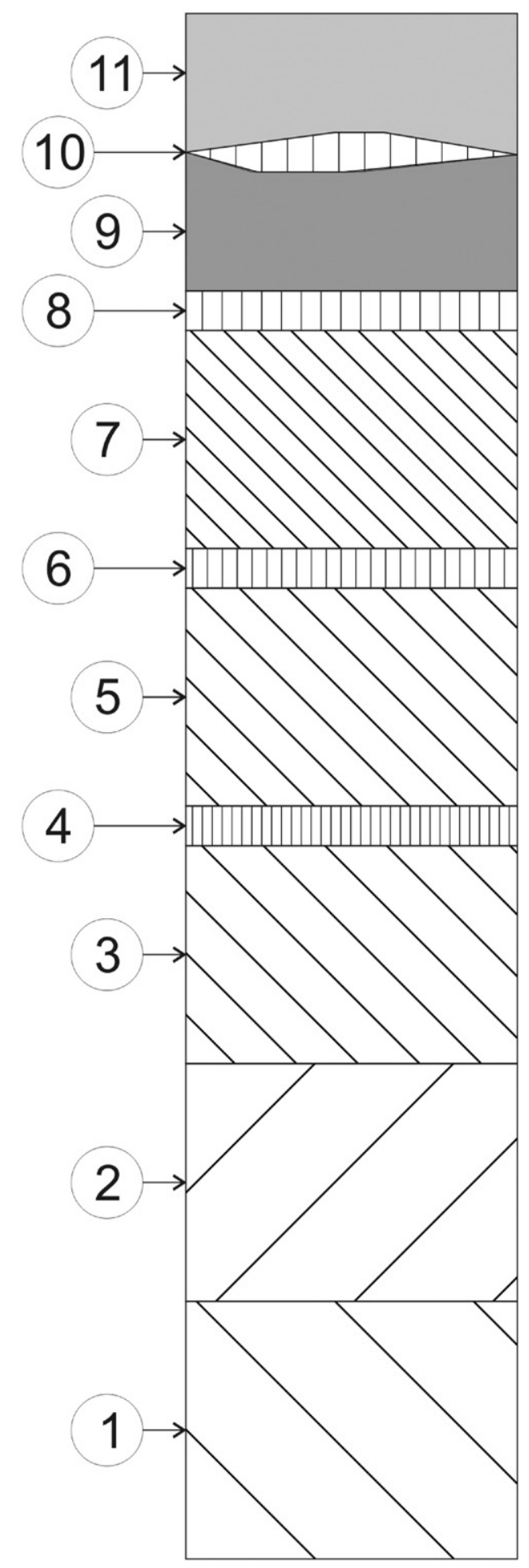

Fig. 2. Idealised sedimentary column for the study area (see description in text). Thickness of the different units not to scale, because they differ between lakes. Some units, especially eolian deposits, are not always present. This is illustrated only for La Postrera IV. 1. Ensenada Formation, 2. Buenos Aires Formation, 3. Luján Formation, Member La Chumbiada, 4. La Postrera I, 5. F. Luján, M. Lobos, 6. La Postrera II, 7. F. Luján, M. Río Salado, 8. La Postrera III, 9. Suballuvial, 10. La Postrera IV, 11. Alluvial.

formation (10; Dangavs, 2005). Finally, above this layer appear the sediments accumulated after European occupation of the territory. They are assigned to the alluvial formation (11; Valentín, 1898). Various authors attribute the beginning of this period to $300-150$ years BP (Villalba, 1994; Villalba, 1990; Thompson et al., 2003; Bertranda et al., 2005; Araneda et al., 2007; Meyer and Wagner, 2009). 
At present, the deposited sediments originate from two main sources: fine dust brought by wind from distant sources on the one hand, and clay, silt and organic matter generated within the lake's basin via erosion of the A horizon on the other. Erosion of lake margins by waves leads to the formation of some carbonate gravels, derived from older sediments. The sediment accumulation leads to a gradual reduction in lake depth and rooting of vegetation, such that the lake is eventually filled and transformed into an intermittent swampy area or 'bañado'. Most lakes have two different environments. Sand and silt are predominant near the margins, where sediments are transported primarily as bed load and fine gravel. Suspended load is predominant in the central regions, with the sediment being formed by silt and clay and, in some cases, fine sand. Naturally, the grain size tends to decrease towards the innermost regions.

\subsection{The brick industry in the humid Pampa and its environmental effects}

Soil is used as a raw material by brick manufacturing industries in the area. The topsoil (A horizon) is exploited for manufacturing traditional, solid bricks, whereas the B (mainly $\mathrm{Bt}$ ) horizon is the major material for producing hollow bricks (Fig. 3). The argiudols are primarily extracted, as well as hapludols and hapluderts, which offer not only the best-quality material but also the highest soil capability and productivity (INTA, 1990; Giménez et al., 1992; Hurtado et al., 2006, 2004; Hurtado, 2015). Most exploitations are limited to the decapitation of the A horizon, but some of them also involve horizon B. Approximately $0.2-0.3 \mathrm{~m}$ of the former is excavated and usually not more than $1.5 \mathrm{~m}$ in the latter. In some cases, the deeper layers are exploited for various purposes (sub-base for roads and buildings, etc.). These layers can be excavated up to a depth of 15-20 m (Fig. 4).

The case of La Plata (approximately 650,000 inhabitants; Fig. 5) is representative of the industry in the area. The brick consumption from 1882 (when the city was founded) to 2001 is estimated to be approximately 250 bricks person $^{-1} \mathrm{a}^{-1}$ (Forte et al., 2004). The current consumption (estimated from data obtained by interviewing key operators in the region) is somewhat lower, 200 bricks person $^{-1} \mathrm{a}^{-1}$, due to changes in the type of buildings and construction techniques. Earlier, solid bricks were primarily used, whereas hollow bricks are used predominantly at present. The production of hollow bricks requires about $0.3-0.4 \mathrm{~m}^{3}$ of soil (depending on the composition of the soil and the amount of waste).

In their analysis, Rivas et al. (2006) showed that the 'human geomorphic footprint' (area affected and volume mobilised) produced by this industry in the area was $5.6 \mathrm{~m}^{2}$ person ${ }^{-1} \mathrm{a}^{-1}$ and $3.7 \mathrm{~m}^{3}$ person ${ }^{-1}$ $\mathrm{a}^{-1}$, respectively. The values for 2006-2012 were $5.7 \mathrm{~m}^{2}$ person ${ }^{-1} \mathrm{a}^{-1}$ and $4.8 \mathrm{~m}^{3}$ person ${ }^{-1} \mathrm{a}^{-1}$, respectively (Hurtado, 2015). Of the total area affected, almost $90 \%$ corresponded to decapitation, although deep excavations have increased recently. The distribution of these areas is shown in Fig. 5. The environmental impact of increasing, widespread excavations surrounding urban areas has been described for this and other regions (Pereyra and Rimoldi, 2003; Pereyra, 2004; Subba Rao and Prathap Reddy, 2004; Rivas et al., 2006; Jordan, 2009; Zuquette et al., 2009; Dal Sasso et al., 2012; Hurtado, 2015). The impact on the humid Pampa includes:

- High-quality soils are lost and productivity sharply declines due to decapitation. Giménez et al. (2002) revealed an up to 95\% reduction in productivity. Nearly $250 \mathrm{~km}^{2}$ (40\% of the total) of the best-quality soils (capability classes I-III; Klingebiel and Montgomery, 1961) around La Plata were lost between 1882 and 2001, half of which accounts for the impact of soil mining (Forte et al., 2004; Hurtado et al., 2008).

- The pollutant-retention capability of soils is reduced and the risk of groundwater pollution increased (Pereyra and Rimoldi, 2003; Pereyra, 2004; FrePlata, 2012; Angheben, 2013).

- Abandoned hollows are formed, with uncontrolled dumping of different, often polluting, types of waste (FrePlata, 2012; Angheben, 2013).

- Stagnant waters are accumulated, with consequent risk of vectorborne disease and drowning. At least 41 deaths have been reported in these abandoned excavations between 1980 and 2011 (Hurtado, 2015). Data on vector-borne diseases have not been collected systematically, although public health personnel in the area has indicated the prevalence of intestinal diseases and other infectious diseases in these areas.

- Lastly, the visual landscape is degraded.

\section{Methodology}

The methodological approach involved the following steps: A). Characterisation of sediments and assessment of suitability. Lakes with sediments as suitable raw material for brick making (surface clayey sediments with similar qualities to currently used soils) were identified. The lakes were selected for sampling and the sediment composition was initially determined. The test bricks were investigated and their technical properties determined. B). Assessment of resources. The
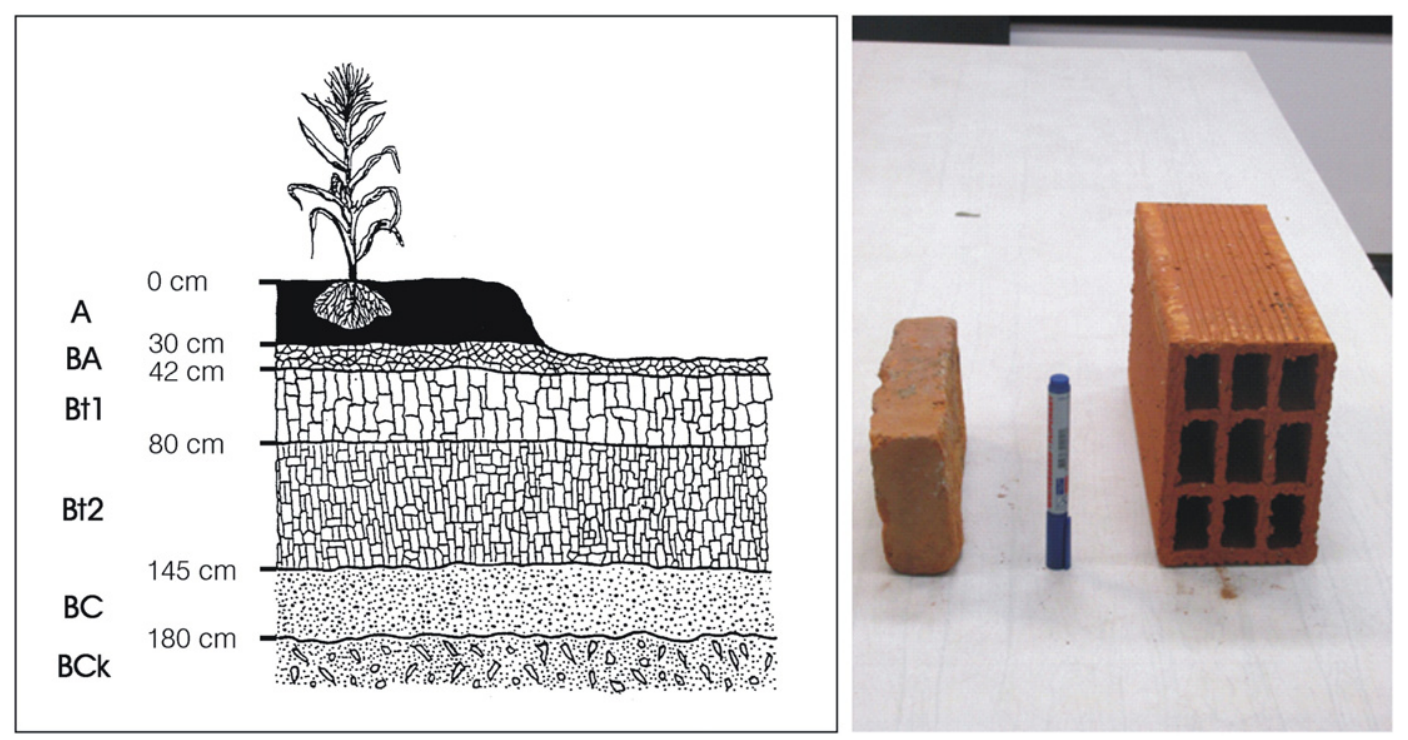

Fig. 3. Typical soil profile of an argiudol and types of bricks made from the A and B horizons. Horizons A and BA used for solid bricks. Horizons Bt1 and Bt2 used for hollow ones. 


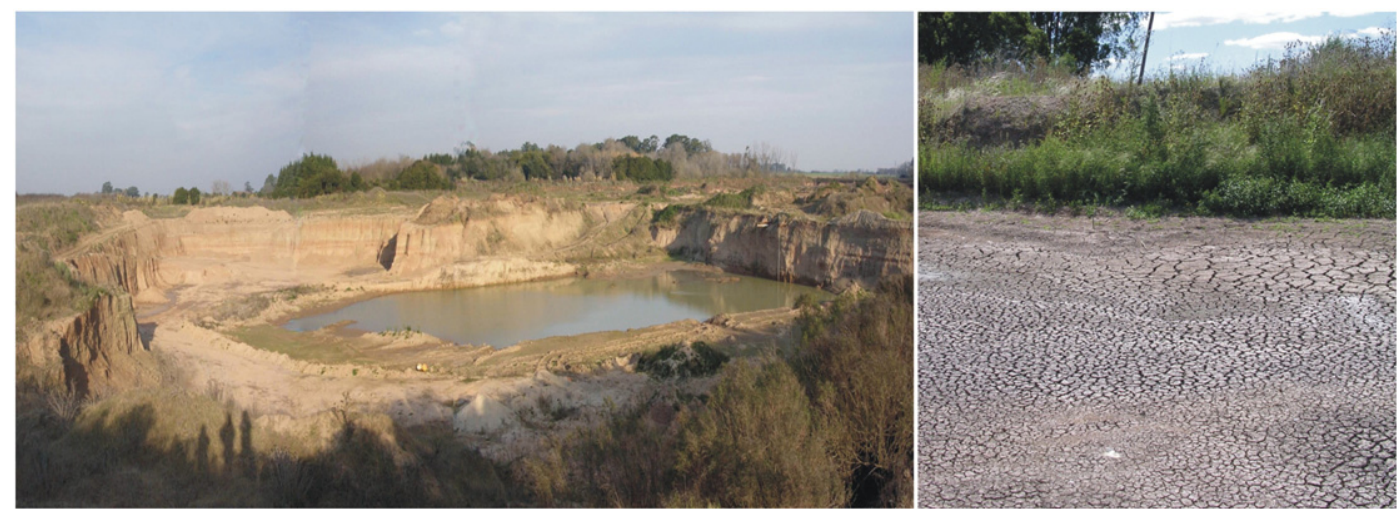

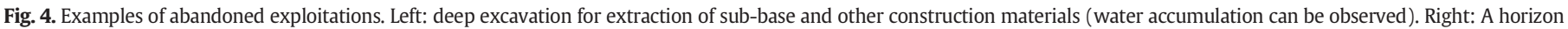
decapitation for brick manufacture, showing desiccation cracks in the B horizon. Observe the difference with non-decapitated terrain in the background.

sediment sequence, especially the thickness of the potentially suitable surface layer, was determined. The existing resources were estimated. C). Assessment of renewal potential. The erosion and sedimentation rates were analysed and the deposit-renewal rate estimated.

A. An initial survey based on some former studies (Dangvas and Blasi, 2002; Dangavs et al., 2006; Dangavs, 2008, Dangavs and Reynaldi, 2008; Dangavs, 2010) was performed, including satellite images and air-photo interpretation. Initially, 95 lakes, 'bañados' and river sectors were identified (Table A; supplementary information). Upon further investigation, 61 were discarded for various reasons, such as high salt or sand content in the sediments or accessibility problems. The remaining water bodies and the analytical methods are listed in Table 1. Ninety-six samples were collected for the characterisation of sediments in terms of the grain size distribution and Atterberg limits. The 'bañados' were extracted during the dry period, using a shovel. In the lakes, short cores were extracted with polyvinyl chloride (PVC) tubes. Based on the data and results thus obtained, a series of lakes and 'bañados' in two study areas (Fig. 6) were selected for the preparation of ceramic pastes and test bricks. Furthermore, to test the suitability of lower-quality sediments (with higher sand content), samples were collected from lakes in a third area (Junín, Fig. 6). The grain size (Kilmer and Alexander, 1949) and Atterberg limits were analysed in detail for these pastes and for commercial pastes.

The test bricks were prepared using sediment samples (either pure or mixed in different proportions), as well as commercial ceramic pastes, to determine the following properties: water absorption capacity, compressive strength and frost behaviour. Analyses were performed according to the IRAM 12566-1 (IRAM. http://www. iram.org.ar/) and CIRSOC 501 (INTI, 2007) guidelines, and the results were compared with the norm requirements.

B. The sedimentary sequences in the lakes were obtained from the literature, including previous works by some of the authors (Doering, 1884; Ameghino, 1889, 1884; Valentín, 1898; Frenguelli, 1957; Fidalgo et al., 1975; Dangavs, 1979; Riggi et al., 1986; Dangvas and Merlo, 1994; Dangvas and Blasi, 1994; Iriondo and Kröhling, 1995; Dangvas and Merlo, 1997; Dangavs and Blasi, 2003, 2002; Dangavs et al., 2006; Dangavs, 2008, Dangavs and Reynaldi, 2008; Dangavs, 2009a,b,c, Dangavs and Mormeneo, 2012; Dangavs and Pierrard, 2013), or they were determined by manually extracting the sediment cores. The maximum water depth in these lakes rarely exceeds $1.5 \mathrm{~m}$, which is $<1 \mathrm{~m}$ in most cases. The thickness of the alluvial (Ameghino, 1889, 1884; Valentín, 1898) and suballuvial (Doering, 1884) sediment layers in the lakes does not typically exceed $1.5 \mathrm{~m}$, the average being approximately $60 \mathrm{~cm}$. Sediments below these two units - the Luján, La Postrera, Ensenada and Buenos
Aires formations (Frenguelli, 1957; Fidalgo et al., 1975; Riggi et al., 1986; Iriondo and Kröhling, 1995) - correspond to fluvial, fluviomarine or aeolian deposits that are unrelated to the present sedimentation. The sediment volume was calculated from data on the area of the lake and thickness of the alluvial plus suballuvial layers. The obtained results were extrapolated to estimate the potential resources in the entire region.

C. The renewal rates of lake sediments were estimated based on two types of data. On the one hand, the age of the alluvial deposits was obtained from the literature, based on which the average sedimentation rates for the period were estimated. On the other hand, the recent erosion rates in the region were also obtained and estimated from the literature. They were used to estimate sediment generation within the lakes' basins and their consequent sediment supply. As expected from previous results (Bonachea et al., 2010; Bruschi et al., 2013), the latter data yielded significantly higher potential sedimentation rates than the former.

\section{Results and discussion}

\subsection{Characteristics of the sediments}

A typical cross section of lake sediments is shown in Fig. 7. The thickness of the suitable surface layer is $0.3-1.0 \mathrm{~m}$. Table B (supplementary information) presents the grain size and Atterberg limits analysed for the extracted samples. Of 96 samples, only nine were unsuitable for preparing ceramic pastes, either directly or in combination with materials available in the surroundings (a common practice in the local industry). Tables $2 \mathrm{~A}$ and $2 \mathrm{~B}$ present the results of the analyses of ceramic pastes made with sediments and commercial pastes, respectively.

Fig. 8 shows the grain size distribution of the sediment samples and of the commercial ceramic pastes. In Fig. 9, the grain size analyses of ceramic pastes are presented in more detail. Some pastes made directly with the sediment have adequate grain size: LSV1 (a mixture of dredge spoil from the lake) and LSV2 (a mixture of sediment samples extracted from the lake). Mixes prepared with sediments from nearby sources were adequate in certain cases (B, B2, C, D, LCRS1 and LCRS2), whereas others were not (LCG1, LCG2, LCG3, LCRS3 and LCRS4, all originating from the Junín area). Finally, mixes C1-5 and D1-5 prepared with sediment and different proportions of fine fluvial sand, equivalent to that from the Rio de la Plata, in the neighbouring area of Magdalena (C1-5 and D1-5), were also found to be adequate.

Table C (supplementary information) summarises the water absorption capacity, resistance to frost and compressive strength 


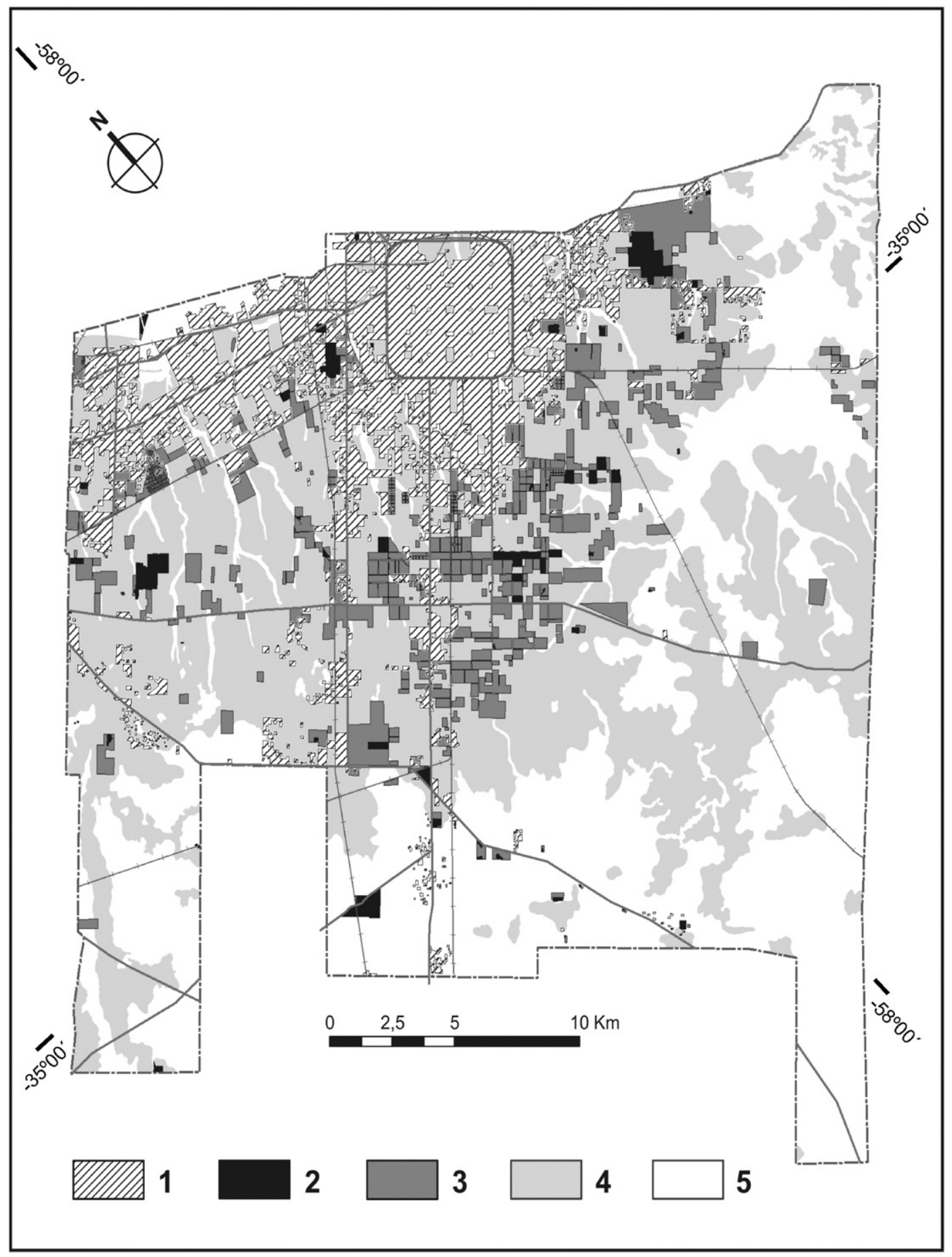

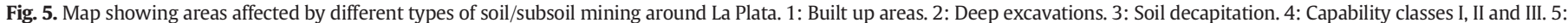
Soils of lower capability class.

determinations. The experimental pastes were found to have $11-15 \%$ water absorption capacity, whereas commercial pastes yielded worse values of $19-26 \%$. The compressive strength was estimated to be $129-141 \mathrm{~kg} \mathrm{~cm}^{-2}$ for experimental pastes and $74-120$ for commercial pastes, which were also worse. Even at higher temperatures ranging from 800 and $900{ }^{\circ} \mathrm{C}$, experimental pastes had superior values to commercial pastes. The frost resistance was adequate in all cases. The properties of the majority of test bricks fall within the norm limits (IRAM, INTI, 2007), even at lower oven temperatures, including bricks with high content of fine fluvial sand
(C4-5 and D4-5). The only exceptions are mixes prepared with sediments from the Junín area, as expected based on the data in Table 2A. Nevertheless, the values do not exceed these norm limits much and are superior to those obtained for the majority of bricks made with commercial pastes.

Bricks made with lake sediments are expected to yield similar (or even better) results than commercial bricks. As indicated earlier, the surface layer used has formed (and is presently forming) by the accumulation of sediment eroded from the A and B soil horizons, the layers exploited by the brick industry. 
Table 1

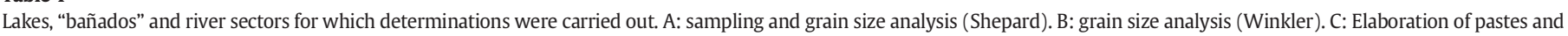

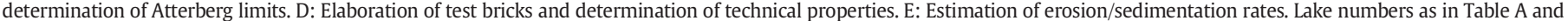
Fig. A (supplementary information). In the case of river sectors (numbers 4, 12, 26, 46, 47 and 48), coordinates of sampling points are indicated in Table A.

\begin{tabular}{|c|c|c|c|c|c|c|c|c|c|}
\hline Lake/“bañado”/river and $\left(\mathrm{N}^{\circ}\right)$ & Determinations & $\begin{array}{l}\text { Area } \\
\text { (ha) }\end{array}$ & $\begin{array}{l}\text { Area basin } \\
\text { (ha) }\end{array}$ & $\begin{array}{l}\text { Thickness } \\
\text { Alluvial } \\
(\mathrm{m})\end{array}$ & $\%$ suitable & $\begin{array}{l}\text { Estimated } \\
\text { exploitable } \\
\text { volume } \\
\left(\times 10^{3}\right)\end{array}$ & $\begin{array}{l}\text { Thickness } \\
\text { Suballuvial } \\
\text { (m) }\end{array}$ & $\%$ suitable & $\begin{array}{l}\text { Estimated } \\
\text { exploitable } \\
\text { volume } \\
\left(\times 10^{3}\right)\end{array}$ \\
\hline Laguna de Gómez (2) & $A, C, D$ & 5200 & - & - & - & - & - & - & - \\
\hline Laguna del Carpincho (3) & A, C, D & 425 & - & - & - & - & - & - & - \\
\hline Rio Salado (upstream Laguna Carpincho; 4) & A, C, D & - & - & - & - & - & - & - & - \\
\hline Laguna Tacurú (9) & A, B, C, D, E & 156 & 14,530 & 0.5 & 100 & 780 & 0.7 & 100 & 1092 \\
\hline Laguna La Bellaca (10) & $\mathrm{A}, \mathrm{B}, \mathrm{C}, \mathrm{D}, \mathrm{E}$ & 65 & & 0.5 & 100 & 325 & 0.7 & 100 & 455 \\
\hline Laguna San Vicente (11) & A, B, C, D, E & 178 & & 0.6 & 100 & 1068 & 0.7 & 100 & 1246 \\
\hline Arroyo San Vicente (downstream Laguna San Vicente; 12) & A, C & - & - & - & - & - & - & - & - \\
\hline Laguna Vitel (49) & $A, C, E$ & 1470 & 51,700 & 0.6 & 50 & 4410 & 0.6 & 50 & 4410 \\
\hline Arroyo Vitel (50) & $\mathrm{A}, \mathrm{C}$ & - & - & - & - & - & - & - & - \\
\hline Laguna Chascomús (51) & $\mathrm{A}, \mathrm{C}$ & 3012 & & - & - & - & - & - & - \\
\hline Laguna Manantiales (57) & $A, C$ & - & - & - & - & - & - & - & - \\
\hline Laguna Del Burro (56) & $\mathrm{A}, \mathrm{C}, \mathrm{E}$ & 1005 & 9900 & 0.5 & 50 & 2512 & 0.3 & 50 & 1508 \\
\hline Laguna Adela (55) & $\mathrm{A}, \mathrm{C}, \mathrm{E}$ & 2085 & 8900 & 0.5 & 50 & 5212 & 0.7 & 50 & 7298 \\
\hline Laguna Chis Chis (58) & $\mathrm{A}, \mathrm{C}$ & 1470 & & 0.4 & 50 & 2867 & 0.5 & 50 & 3675 \\
\hline Laguna La Salada (66) & $A, C$ & - & - & - & - & - & - & - & - \\
\hline Laguna San Juan de la Leña (43) & $\mathrm{E}$ & 238 & 2131 & 0.4 & 50 & 476 & 0.7 & 50 & 833 \\
\hline Laguna Espadaña de Pérez (45) & $\mathrm{E}$ & 290 & & 0.4 & 50 & 580 & 0.7 & 50 & 1015 \\
\hline Laguna Chica (44) & $\mathrm{E}$ & 75 & & 0.4 & 50 & 525 & 0.7 & 50 & 263 \\
\hline Laguna Cildañez (42) & $\mathrm{E}$ & 297 & & 0.4 & 50 & 194 & 0.7 & 50 & 340 \\
\hline Laguna Quinteros (37) & $\mathrm{E}$ & 330 & 9019 & 0.3 & 50 & 495 & 0.4 & 50 & 660 \\
\hline Laguna del Medio (39) & $\mathrm{E}$ & 546 & & 0.65 & 50 & 1776 & 0.63 & 50 & 1721 \\
\hline Laguna Esquivel (41) & $\mathrm{E}$ & 2453 & & 0.65 & 50 & 7973 & 0.63 & 50 & 7728 \\
\hline Laguna El Espartillar (38) & $\mathrm{E}$ & 1252 & & 0.65 & 50 & 4071 & 0.63 & 50 & 3945 \\
\hline Bañado La Yalca (67) & $\mathrm{A}, \mathrm{C}$ & 879 & - & 1 & 100 & 8973 & * & $*$ & * \\
\hline Bañado La Libertad (68) & A, B, C, D & 348 & - & 1 & 100 & 3484 & $*$ & $*$ & * \\
\hline Bañado Don Mario (69) & A, B, C, D & 606 & - & 1 & 100 & 6059 & $*$ & $*$ & * \\
\hline Bañado La Eloísa (72) & A, B, C, D & 756 & - & 1 & 100 & 7564 & $*$ & $*$ & * \\
\hline Bañado San Juan de María (71) & A, B, C, D & 814 & - & 1 & 100 & 8144 & * & * & * \\
\hline Bañado Miraflores (70) & A, B, C, D & 630 & - & 1 & 100 & 6304 & * & * & * \\
\hline Laguna Las Perdices N (18) & A, C & 825 & - & 0.45 & 50 & 1856 & 0.45 & 50 & 1856 \\
\hline Río Salado (upstream National Route $\mathrm{N}^{\circ} 3 ; 26$ ) & $A, C$ & - & - & - & - & - & - & - & - \\
\hline Río Salado (downstream city of Gral. Belgrano; 46) & $\mathrm{A}, \mathrm{C}$ & - & - & - & - & - & - & - & - \\
\hline Río Salado (downstream city of Gral. Belgrano; 47) & $A, C$ & - & - & - & - & - & - & - & - \\
\hline Río Salado (downstream city of Gral. Belgrano; 48) & $\mathrm{A}, \mathrm{C}$ & - & - & - & - & - & - & - & - \\
\hline
\end{tabular}

\subsection{Assessment of resources}

The amount of sediment available was estimated based on the data in Table 1. As presented in the table, the total area of the lakes and 'bañados' is approximately $250 \mathrm{~km}^{2}$. The area of water bodies with suitable sediment, as indicated by the data, is approximately $150 \mathrm{~km}^{2}$ (105 km² of which correspond to bodies with experimental data obtained for this work). That is, 60-40\% of the lakes and 'bañados' analysed have sediments that can be used to manufacture bricks. In certain cases (for instance, Tacurú, La Bellaca and San Vicente and all 'bañados'), all of the alluvial and suballuvial units are suitable for brick making. However, in other lakes, the sediments around the outer parts are coarser grained and of lower quality. Therefore, only 50\% of the materials in the latter can be used for brick making, a very conservative estimate (see Table 1 ).

If the proportion ( $40 \%$ in a conservative estimate) of lakes and 'bañados' with suitable sediment was the same for the entire province and the study area, the potentially suitable area would be $>1500 \mathrm{~km}^{2}$. However, the selection of water bodies considered here is somewhat biased. Therefore, a conservative extrapolation was made, considering that only $20 \%$ of the lake/'bañado' area in the province $\left(900 \mathrm{~km}^{2}\right)$ is likely to contain exploitable resources. For a more conservative and careful estimate, the total area with characteristics similar to those described here is unlikely to be $<500 \mathrm{~km}^{2}$. Considering an average thickness of $60 \mathrm{~cm}$ for alluvial plus suballuvial sediments, and that only $50 \%$ would be adequate, we obtain a total of $300 \times 10^{6} \mathrm{~m}^{3}$. With the present consumption rate of 200 bricks person $^{-1} \mathrm{a}^{-1}$ (0.3-0.4 $\mathrm{m}^{3}$ person $\left.{ }^{-1} \mathrm{a}^{-1}\right)$, this can sufficiently supply the city and province of Buenos Aires (approximately 19 million people) for a period of $40-50$ years.

It is given that these sediments are extracted, if possible, from specific locations, which have been thoroughly analysed for their technical, environmental and economic feasibility. To further asses the feasibility of exploiting lake sediments, two lake/'bañado' complexes were analysed in detail, as well as three lakes in the San Vicente area (San Vicente, La Bellaca and Tacurú), and the Don Mario, La Libertad and Laguna La Yalca 'bañados', in Chascomús (Fig. 6). This analysis was undertaken at the request and with the cooperation of local entrepreneurs seeking to exploit this potential resource. The first complex covers 399 ha. The average sediment thickness (both alluvial plus suballuvial suitable for brick making) is $1 \mathrm{~m}$ and the total volume $4 \times 10^{6} \mathrm{~m}^{3}$. As $1 \mathrm{~m}^{3}$ of material is needed to produce 600 bricks, $2.4 \times 10^{9}$ bricks are manufactured. This is equivalent to 250 years' worth of production of one of the large brick industries in the region. In the Chascomús area, to obtain material of brick-making quality, the 'bañado' sediments (clay rich) must be mixed with lake sediment (silt-sand rich) in the proportion $80 / 20 \%$. This type of mixing is a common practice in the local industry. The thickness of suitable sediments is $1 \mathrm{~m}$ in the 'bañados' (650 ha) and $0.25 \mathrm{~m}$ in the lake (950 ha). Upon mixing the entire 'bañado' sediment with approximately half of the lake sediment, a total of $4.7 \times 10^{9}$ bricks can be produced, equivalent to 500 years' worth of production of one of the many large local industries. In spite of assuming a large error in the presented estimates, these sediments represent an interesting potential resource.

Although this analysis indicates the feasibility of exploiting this potential resource, additional and more in-depth analyses in specific, 


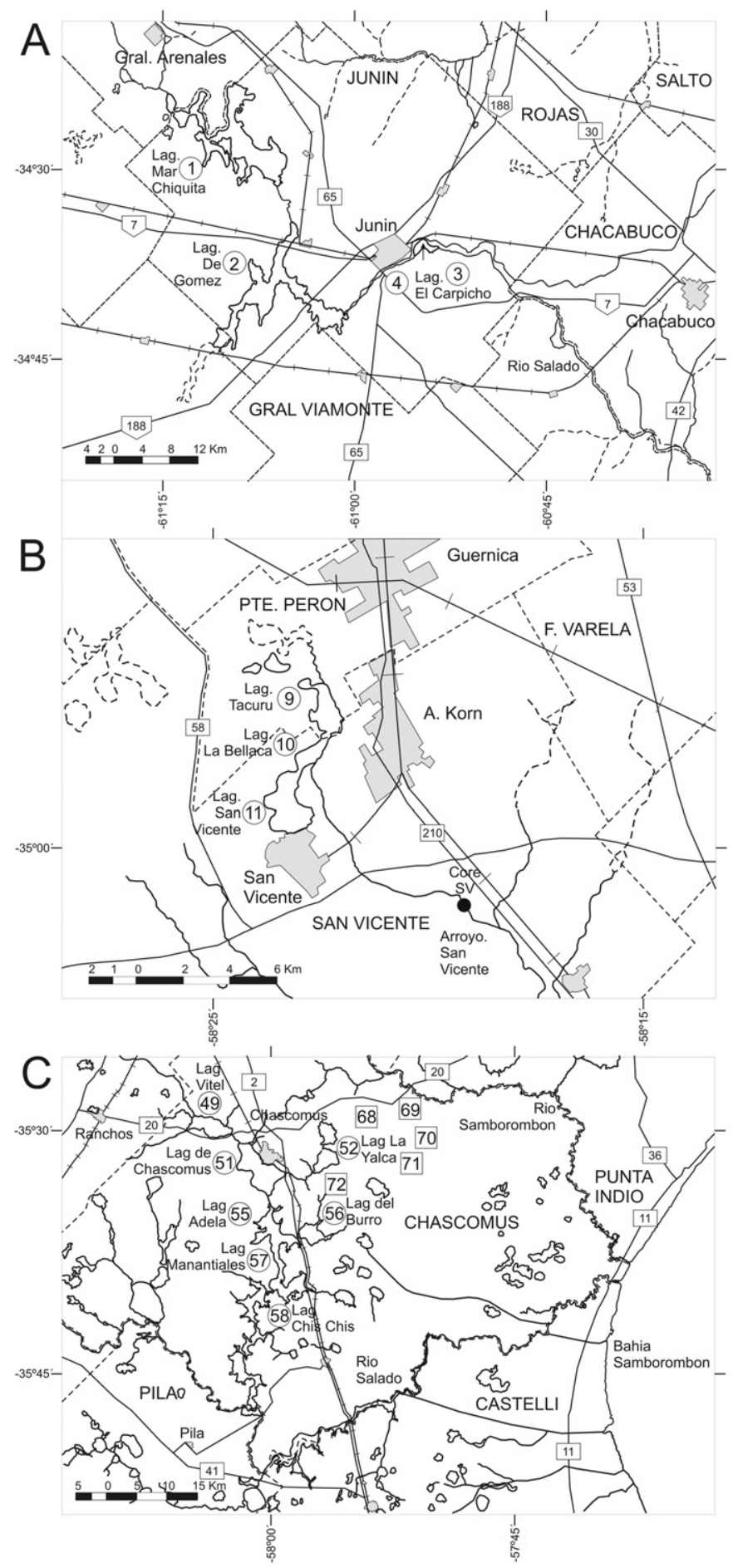

Fig. 6. Location of the three areas selected (see Fig. 1 and A) for the extraction of sediment and elaboration of test bricks. Lake (circles, names) and "bañado" (squares) numbers correspond to the ones in Table A. Location of core sampling point in Arroyo San Vicente (Core SV) is shown in 6B.

selected water bodies are needed. Other factors, such as mining and transport costs and environmental constraints for the new means of exploitation, must be considered before determining the feasibility. In a preliminary analysis of 'bañados', the excavation costs may be the same as that of the present methods of extracting soil. This is because extraction can easily be performed during the dry period, using the same techniques. Its impact on the soil and productive activities would, in principle, be lower, because these areas have low-quality and are only used as low-intensity pasturelands.

\subsection{Assessment of renewal rate}

The recent increase in sedimentation rates observed in the region has led to the filling of several lakes, which have been transformed into intermittent wetlands or 'bañados'. For instance, Laguna Chica and Laguna Espadaña de Pérez have been completely filled (Fig. A; supplementary information). Other lakes, such as Quinteros, Monte, Las Perdices, Adela, Cerrillo del Medio, Tacurú, La Bellaca and San Vicente (Fig. 6 and Fig. A; supplementary information), are at an advanced stage of infilling (Dangvas and Merlo, 1997, 1994; Dangavs and Reynaldi, 2008; Dangavs and Mormeneo, 2012; Dangavs and Pierrard, 2013). Thus, the sediment accumulation rate may be comparable to the current exploitation rate.

The thickness of the suballuvial and alluvial formations described in Section 2.2 was obtained from the literature (Dangavs, 1979, 2009a,b,c, 2008, 2005; Dangavs and Blasi, 2003, 2002; Dangvas and Merlo, 1994 1997, 1994; Dangavs et al., 2006; Dangavs and Reynaldi, 2008; Dangavs and Mormeneo, 2012; Dangavs and Pierrard, 2013) and from field surveys. The accumulation period was considered to be 700 years for the suballuvial and between 300 (earliest proposed limit for the LIA) and 200 (start of extensive European occupation) years for the alluvial. Based on these age estimates, average sedimentation rates of $0.8 \mathrm{~mm} /$ year for the suballuvial and $1.6-2.4 \mathrm{~mm} /$ year (300-200 years) for the alluvial were obtained.

Table D (supplementary information) presents data and estimates of the current erosion rates in the region, as obtained from the literature. The rates are in the order of 1-1.5 mm/year in farmland-pasture areas with a gradient of $<0.5^{\circ}$ (Michelena et al., 1988, 1991; Bujan et al., 2003; Frank and Viglizzo, 2010; Kraemer et al., 2013) and approximately $0.3 \mathrm{~mm} /$ year in completely flat areas with nearly natural vegetation or pastures (Michelena, 2014). The potential erosion rate (depending on local conditions as well as land use and management factors) is estimated to be $0.3-3.7 \mathrm{~mm} / \mathrm{year}$. As the lower limit represents highly infrequent conditions, actual erosion is likely to occur a bit more frequently. Therefore, sediment generation under the present (and presumably near-future) conditions ranges from 300 to $3700 \mathrm{~m}^{3} \mathrm{~km}^{-2} \mathrm{a}^{-1}$. These values were used to calculate the potential sediment generation in a series of lake basins, for which the watersheds could be determined. Oftentimes, this calculation is difficult, due to the extremely low gradients in the region. Table 3 summarises the results.

The data in Table 3 indicate that the area of the 14 lakes considered is just over $100 \mathrm{~km}^{2}$. The estimated sedimentation rates for these lakes vary widely $\left(1-140 \mathrm{~mm} \mathrm{a}^{-1}\right)$, but the total annual sedimentation is found to range from 300,000 to $3,800,000 \mathrm{~m}^{3} /$ year. This is based on the assumption that all generated sediment is carried into the basin and that the density of both the eroded topsoil and sediment accumulated in the lake is $1 \mathrm{t} \mathrm{m}^{-3}$. However, these assumptions are only a rough approximation. Using the densities determined for both types of materials (an average of $1.1 \mathrm{t} \mathrm{m}^{-3}$ for the topsoil and $1.65 \mathrm{t} \mathrm{m}^{-3}$ for the sediment), the rates obtained would be in the order of $200,000-2,500,000 \mathrm{~m}^{3} /$ year. Further, given that only half of the sediment generated in the basin is actually carried into the lake (although eventually most of it will be), the amount of material accumulated annually in the 14 lakes is estimated to be $100,000-1,250,000 \mathrm{~m}^{-3}$. This is equivalent to the needs of $300,000-4,000,000$ individuals at the present consumption rates. If the estimates for the analysed area (5-6\% of the total lake/bañado area in the region) are extrapolated to the whole humid Pampa, the annual supply of sediment of brick-making quality can cover the needs of a significant proportion of the population in the city and province of Buenos Aires.

An independent observation in Arroyo San Vicente (Fig. 6), which connects Laguna San Vicente to a 'bañado', offers an indirect method of assessing the reliability of the previous estimates. As shown in Table 3, the sedimentation rates for Laguna San Vicente are estimated to be $10-135 \mathrm{~mm} \mathrm{a}^{-1}$. The Arroyo San Vicente was dredged in 2003, wherein the sediment layer on top of the 'Pampean' unit 


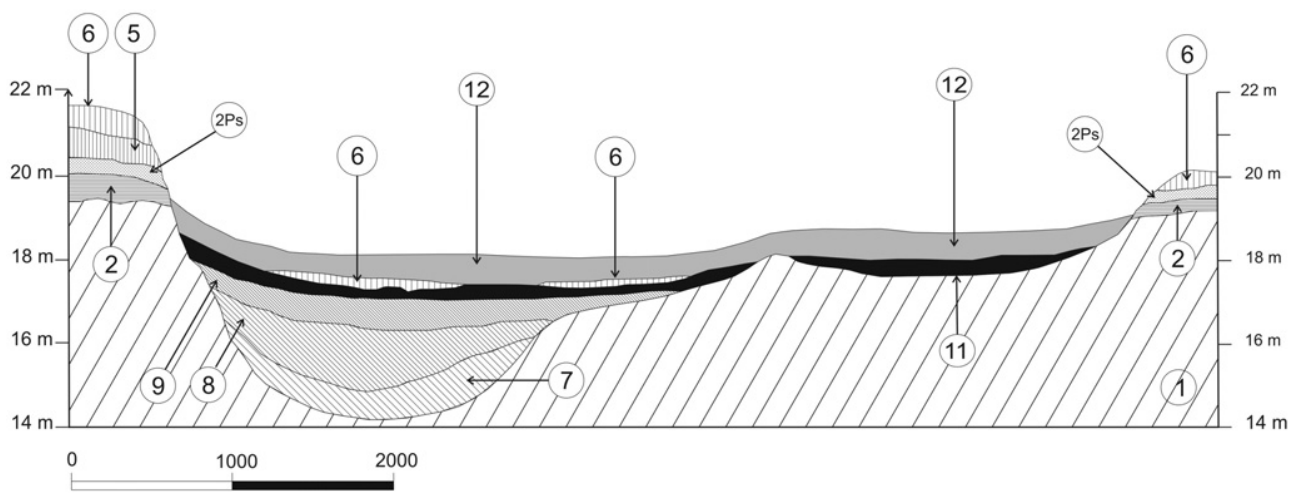

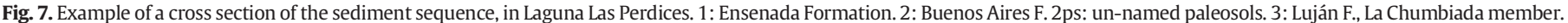
5: Luján F., Lobos member. 7: Lujan F., Rio Salado member. 8: La Postrera III. 9: Suballuvial. 10: La Postrera IV. 11: Alluvial.

(easily recognisable due to its reddish colour and greater compaction) was removed. The present sediment thickness in a recently extracted core (core SV, Fig. 6B) is estimated to be $17 \mathrm{~cm}$, equivalent to $15 \mathrm{~mm} \mathrm{a}^{-1}$, which is somewhat higher than the lower estimate mentioned above. The grain size and Atterberg limits for the sediment in this core are as follows: $<2 \mu, 36.59 ; 2-20 \mu, 39.63 ;>20 \mu, 23.78$ (36/40/24); LL, 40.25; LP, 20.78; and PI, 19.47 (40/21/19). These values represent the optimum conditions for ceramic use, thus confirming the studied sediment to be a potential resource. The sampling point was located in a channel affected by stream flow and downstream of three

Table 2A

Grain size distribution (Kilmer and Alexander, 1949) and Atterberg limits of experimental pastes.

\begin{tabular}{|c|c|c|}
\hline & $\begin{array}{l}\text { Grain size distribution } \\
\% 2 \mu / 2-20 \mu />20 \mu\end{array}$ & $\begin{array}{l}\text { Atterberg limits } \\
\text { LL/PL/PI }\end{array}$ \\
\hline LCG1 & $15 / 13 / 72$ & $33 / 23 / 10$ \\
\hline LCG2 & $16 / 12 / 72$ & $38 / 26 / 12$ \\
\hline LCG3 & $7 / 18 / 75$ & $26 / \mathrm{nd} / \mathrm{nd}$ \\
\hline LCRS $1^{\text {a }}$ & $17 / 14 / 68$ & $35 / 23 / 12$ \\
\hline LCRS2 $^{\mathrm{a}}$ & $18 / 16 / 66$ & $40 / 25 / 15$ \\
\hline LCRS3 & $11 / 17 / 72$ & $30 / \mathrm{nd} / \mathrm{nd}$ \\
\hline LCRS $^{\mathrm{a}}{ }^{\mathrm{a}}$ & $6 / 18 / 76$ & $25 / \mathrm{nd} / \mathrm{nd}$ \\
\hline $\mathrm{LSV}^{\mathrm{a}}$ & $18 / 26 / 56$ & $28 / 25 / 3$ \\
\hline $\mathrm{LSV}^{\mathrm{a}}$ & $29 / 21 / 50$ & $36 / 23 / 13$ \\
\hline B & $35 / 19 / 46$ & $55 / 23 / 32$ \\
\hline $\mathrm{B}^{\mathrm{a}}$ & $30 / 14 / 56$ & $38 / 16 / 22$ \\
\hline$C$ & $50 / 21 / 29$ & $37 / 44 / 23$ \\
\hline $\mathrm{C} 1$ & $47 / 25 / 28$ & $63 / 24 / 39$ \\
\hline $\mathrm{C} 2$ & $40 / 15 / 45$ & $50 / 21 / 29$ \\
\hline $\mathrm{C} 3$ & $34 / 13 / 53$ & $44 / 17 / 27$ \\
\hline$C 4^{\mathrm{a}}$ & $28 / 11 / 60$ & $38 / 14 / 24$ \\
\hline $\mathrm{C5}^{\mathrm{a}}$ & $25 / 10 / 65$ & $30 / 14 / 16$ \\
\hline $\mathrm{D}$ & $46 / 25 / 29$ & $62 / 28 / 34$ \\
\hline D1 & $44 / 16 / 40$ & $59 / 25 / 34$ \\
\hline D2 & $40 / 12 / 42$ & $51 / 23 / 28$ \\
\hline D3 & $35 / 13 / 52$ & $40 / 21 / 19$ \\
\hline $\mathrm{D} 4^{\mathrm{a}}$ & $29 / 13 / 58$ & $36 / 17 / 19$ \\
\hline $\mathrm{D} 5^{\mathrm{a}}$ & $23 / 11 / 66$ & $29 / 14 / 15$ \\
\hline
\end{tabular}

LCG. Mix of sediments from Laguna del Carpincho (3) y Laguna de Gómez (Junín; 2). LCRS.1, 2, 3, 4. Mixes of silty sediments from Laguna del Carpincho (3) and silty-sandy sediments from the Rio Salado (Junín; 26).

LSV1. A mix of sediments dredged from Laguna San Vicente (11) and accumulated near its margin.

LSV2. Sediments from Laguna San Vicente (11).

B. Mix of sediments from the "bañados" D. Mario (69), La Libertad (68), San Juan de María (71), La Eloisa (72) and Miraflores (70; Chascomús).

B2. The same mix of "bañado" sediments, with silty-sandy sediment from Laguna La Yalca (52; Chascomús).

C: Sediments from Bañado de Don Mario (69; Chascomús).

D. Sediments from Bañado La Libertad (68; Chascomús).

C1-5 and D1-5 correspond to mixes of sediments from the "bañados" with progressively greater proportion of fine fluvial sand (10-50\%).

LL: liquid limit. PL: plastic limit. PI: plasticity index.

a Pastes selected for the elaboration of test bricks. lakes (Tacurú, La Bellaca and San Vicente) with shallow waters and abundant vegetation. It follows then that most of the sediment is deposited in the lakes and the sedimentation rates are significantly higher.

Thus, the present (and near-future) sedimentation rates are approximately one order of magnitude greater than those registered for the alluvial layer and, in turn, twice that for the suballuvial layer. This increase is most likely due to the increasing human modification of the land surface (Walling, 2006; Tarolli and Sofia, 2016), reflecting a progressively greater, human-induced geomorphic change. The results presented here are in line with the concept of a 'great geomorphic acceleration' (Bruschi et al., 2012a,b, 2013) after the mid-20th century, which coincides coinciding with the 'Great Acceleration' that marks the start of the Anthropocene (Steffen et al., 2015; Waters et al., 2016).

Table 2B

Grain size distribution (Kilmer and Alexander, 1949) and Atterberg limits of commercial pastes.

\begin{tabular}{|c|c|c|}
\hline Commercial & $\begin{array}{l}\text { Grain size distribution } \\
\% 2 \mu / 2-20 \mu />20 \mu\end{array}$ & $\begin{array}{l}\text { Atterberg limits } \\
\text { LL/PL/PI }\end{array}$ \\
\hline LP1 & $25 / 31 / 44$ & $44 / 25 / 18$ \\
\hline LP2 & $32 / 27 / 41$ & $35 / 23 / 12$ \\
\hline BR1 & $33 / 26 / 41$ & $43 / 24 / 19$ \\
\hline BR2 & $25 / 38 / 37$ & $39 / 24 / 15$ \\
\hline BR3 & $26 / 35 / 39$ & $44 / 29 / 15$ \\
\hline BR4 & $26 / 37 / 37$ & $42 / 27 / 15$ \\
\hline FV1 & $24 / 28 / 48$ & $47 / 26 / 21$ \\
\hline FV2 & $26 / 38 / 36$ & $39 / 25 / 14$ \\
\hline FV3 & $34 / 31 / 35$ & $42 / 27 / 15$ \\
\hline LH1 & $39 / 22 / 39$ & $52 / 27 / 25$ \\
\hline LH2 & $16 / 31 / 53$ & $41 / 22 / 19$ \\
\hline EZ1 & $27 / 36 / 37$ & $40 / 21 / 19$ \\
\hline EZ2 & $26 / 35 / 39$ & $41 / 22 / 19$ \\
\hline EZ3 & $25 / 39 / 36$ & $47 / 26 / 21$ \\
\hline EZ4 & $27 / 38 / 36$ & $50 / 25 / 25$ \\
\hline CA1 & $33 / 30 / 37$ & $40 / 22 / 18$ \\
\hline CA2 & $37 / 18 / 45$ & $38 / 21 / 17$ \\
\hline CA3 & $29 / 24 / 47$ & $43 / 26 / 17$ \\
\hline CA4 & $18 / 35 / 47$ & $45 / 22 / 23$ \\
\hline CA5 & $35 / 15 / 50$ & $42 / 24 / 18$ \\
\hline CA6 & $34 / 26 / 40$ & $45 / 25 / 20$ \\
\hline MP1 & $29 / 29 / 42$ & $47 / 22 / 25$ \\
\hline MP2 & $12 / 58 / 30$ & $47 / 23 / 24$ \\
\hline MP3 & $33 / 29 / 38$ & $47 / 22 / 25$ \\
\hline MP4 & $18 / 41 / 38$ & $46 / 20 / 26$ \\
\hline MP5 & $24 / 39 / 37$ & $53 / 23 / 30$ \\
\hline MP6 & $24 / 44 / 32$ & $48 / 24 / 24$ \\
\hline MP7 & $23 / 25 / 52$ & $48 / 24 / 24$ \\
\hline MP8 & $29 / 31 / 40$ & $50 / 22 / 28$ \\
\hline MP9 & $25 / 32 / 43$ & $49 / 23 / 26$ \\
\hline
\end{tabular}

Ceramic pastes obtained from industrial establishments of the following localities: LP: La Plata; BR: Brandsen; FV: Florencio Varela; LH: Las Heras; EZ: Ezeiza; CA: Cañuelas; MP: Marcos Paz. LL: liquid limit. PL: plastic limit. PI: plasticity index. 

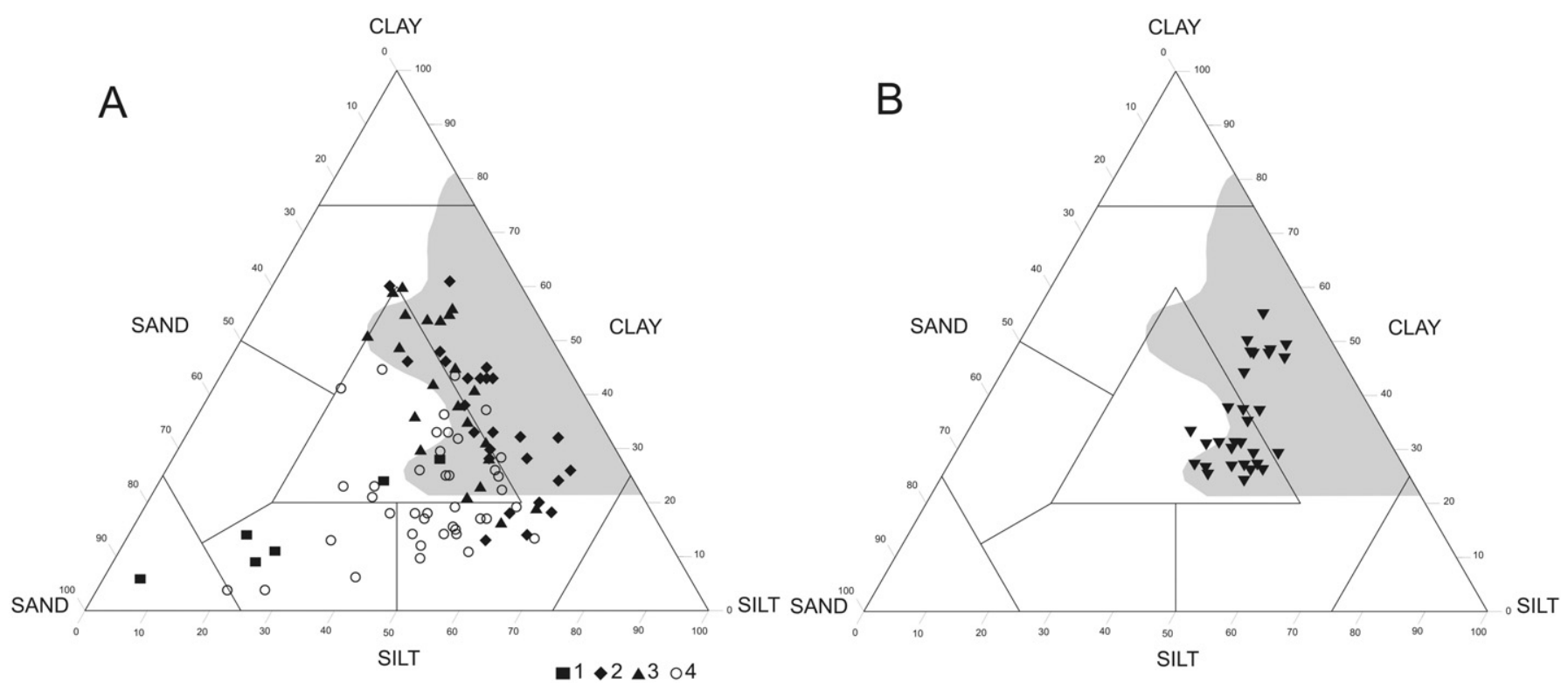

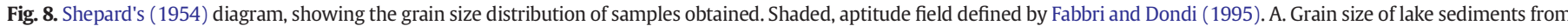

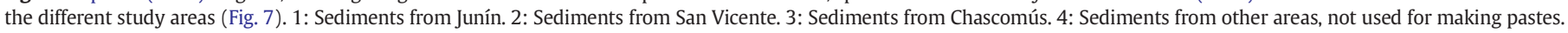
B. Grain size of ceramic pastes from the brick industry.

\section{Conclusions}

The results show that the majority of the sediment recently accumulated in the lakes of the humid Pampa are similar or superior to the topsoil currently used for brick making in terms of composition and properties. In addition, the existing resources are likely to adequately cover the needs of the industry for several decades, and the sediment is presently accumulating at a rate comparable to the current exploitation rates. Thus, sediments from lakes and swampy areas represent a practical alternative to soil mining, thus potentially eliminating this type of activity, and its related environmental impacts.
The recent increase in the sedimentation rate seems to reflect the anthropogenic geomorphic change (the great geomorphic acceleration characterising the Anthropocene?) affecting the Pampa region. The rates were much lower in earlier historical periods, more so before European settlement and modification of surface geologic processes.

If the present results are confirmed by the new study under way, this economic activity can be made more efficient and sustainable. Due to the several lakes and 'bañados' in the region, sufficient resources of good quality to cover the needs of the industry for many decades (perhaps centuries) are highly likely to be present. Moreover, humanenhanced erosion in the region may increase the sedimentation rates,
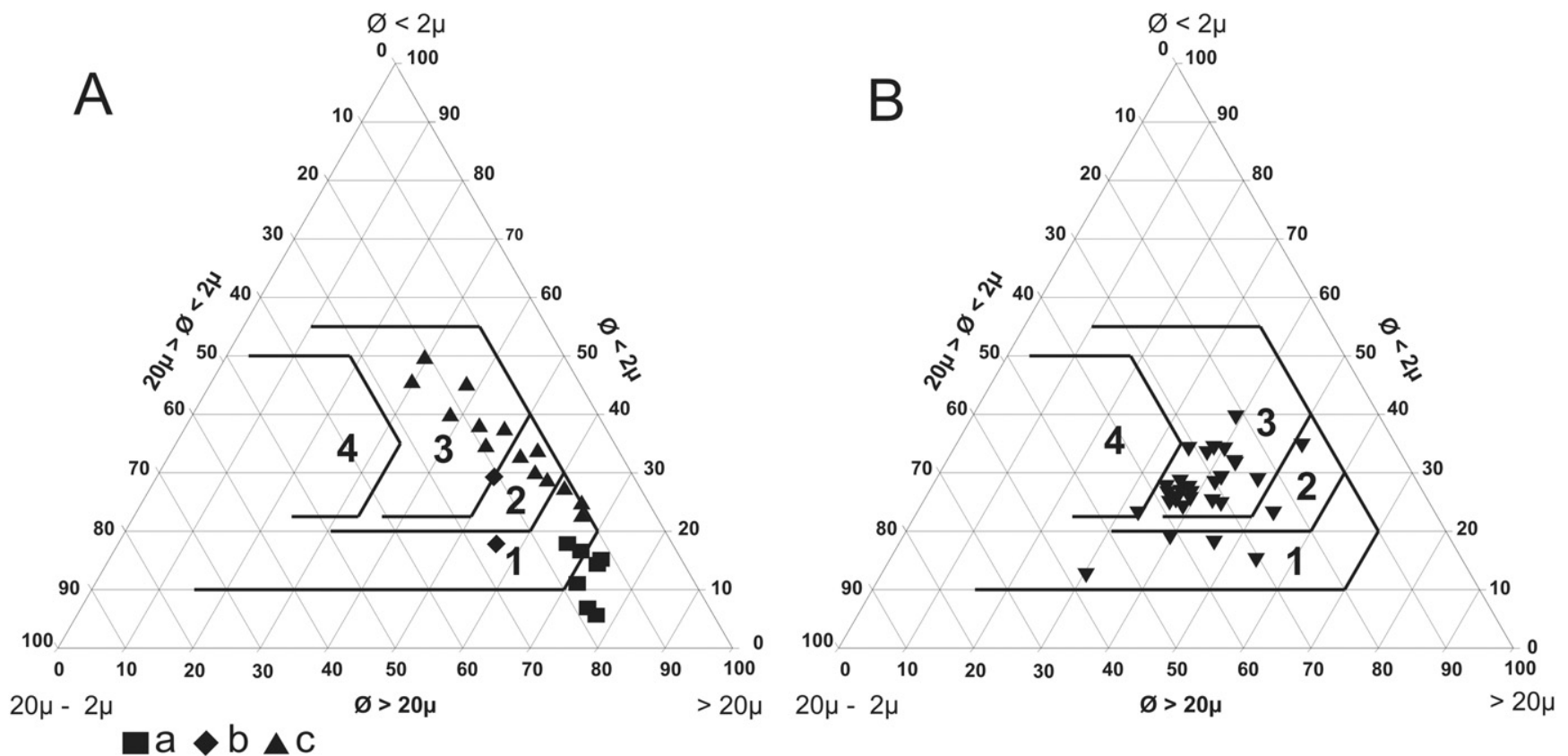

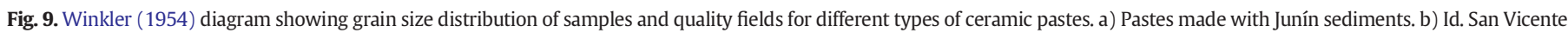
c) Id. Chascomús. 1: Quality field for common bricks. 2. Id. Vertically perforated bricks. 3: Tiles and light blocks. 4- Blocks and hollow bricks. 
Table 3

Estimates of sediment generation and accumulation in several basins/lakes. The range of erosion rates considered is $0.3-3.7 \mathrm{~mm} \cdot \mathrm{a}^{-1}$. Sources and information used for the calculations are presented in Table D (supplementary information).

\begin{tabular}{lllll}
\hline Lake $\left(\mathrm{N}^{\circ}\right)$ & $\begin{array}{l}\text { Area } \\
\text { basin } \\
(\mathrm{ha})\end{array}$ & $\begin{array}{l}\text { Area } \\
\text { lake } \\
\text { (ha) }\end{array}$ & $\begin{array}{l}\text { Sedimentation } \\
\text { rate } \\
\left(\mathrm{max} / \mathrm{min} \mathrm{mm} \cdot \mathrm{a}^{-1}\right)\end{array}$ & $\begin{array}{l}\text { Total volume } \\
(\mathrm{max} / \mathrm{min} \\
\left.10^{3} \mathrm{~m}^{3} \cdot \mathrm{a}^{-1}\right)\end{array}$ \\
\hline Vitel (49) & 51,700 & 1470 & $143.7 / 11.7$ & $2112 / 172$ \\
Adela (55) & 8900 & 2085 & $15.8 / 1.3$ & $329 / 27$ \\
del Burro (56) & 9900 & 1005 & $36.4 / 3$ & $365.8 / 30.2$ \\
SJ de la Leña (43) & 2131 & 238 & $11.3 / 0.9$ & $26.9 / 2.1$ \\
Espadaña de Pérez (45) & & 290 & & $32.8 / 2.6$ \\
Chica (44) & & 75 & & $8.5 / 0.7$ \\
Cildañez (42) & & 297 & & $33.6 / 2.7$ \\
Quinteros (37) & 9019 & 330 & $7.3 / 0.6$ & $24.1 / 2$ \\
del Medio (39) & & 546 & & $39.9 / 3.3$ \\
Esquivel (41) & & 2453 & & $179.1 / 14.7$ \\
El Espartillar (38) & & 1252 & & $91.4 / 7.5$ \\
Tacurú (9) & 14,530 & 156 & $134.7 / 10.9$ & $210.1 / 17$ \\
La Bellaca (10) & & 65 & & $87.6 / 7.1$ \\
San Vicente (11) & & 178 & & $239.8 / 19.4$ \\
\hline
\end{tabular}

making lake sediments a renewable resource. The method presented can be applied to other large plains that lack materials for construction but is commonly exploited for brick making. Research is currently under way to analyse thoroughly and further assess the resource potential of the two locations.

Supplementary data to this article can be found online at http://dx. doi.org/10.1016/j.catena.2016.02.006.

\section{Acknowledgements}

This work was supported by the projects PIT-AP/UNLP 2010, PICT 2013-1685, ANPCyT (Argentina) and UC29.P001.64004 (Spain). The authors acknowledge Prof. E. Latrubesse and one anonymous reviewer for their comments and Bronwen G. Brown for language revision.

\section{References}

Ameghino, F., 1884. Excursiones geológicas y paleontológicas en la provincia de Buenos Aires. Bol. Acad. Nac. Cienc. Córdoba 6, 161-257.

Ameghino, F., 1889. Contribución al conocimiento de los mamíferos fósiles de la República Argentina. Acad. Nac. Cienc. Córdoba 6.

Angheben, E., 2013. Estudio ecohidrológico de la cuenca urbana de La Cava de Villa Itatí. Universidad Nacional de la Plata, Quilmes, provincia de Buenos Aires (MS Thesis)

Araneda, A., Torrejón, F., Aguayo, M., Torres, L., Cruces, F., Cisternas, M., Urrutia, R., 2007. Historical records of San Rafael glacier advances (North Patagonian Icefield): another clue to 'Little Ice Age' timing in southern Chile? The Holocene 17 (7), 987-998.

Bertranda, S., Boësa, X., Castiauxa, J., Charletb, F., Urrutiac, R., Espinozac, C., Lepointd, G., Charliere, B., Fage, N., 2005. Temporal evolution of sediment supply in Lago Puyehue (Southern Chile) during the last 600 years and its climatic significance. Quat. Res. 64 (2), 163-174.

Bhatnagarjm, J.M. Goel, R.K., Gupta, R.G., 1994. Brick-making characteristics of river sediments of the South West Bengal region of India. Constr. Build. Mater. 8 (3), 177-183.

Bonachea, J., Bruschi, V.M., Hurtado, M., Forte, L.M., da Silva, M., Etcheverry, R., Cavallotto J.L., Dantas, M., Pejon, O., Zuquette, L., Bezerra, M.A., Remondo, J., Rivas, V., Gómez Arozamena, J., Fernández, G., Cendrero, A., 2010. Natural and human forcing in recent geomorphic change; case studies in the Rio de la Plata basin. Sci. Total Environ. 408, 2674-2695

Bruschi, V.M., Bonachea, J., Remondo, J., Forte, L.M., Hurtado, M.A., Cendrero, A., 2012a ¿Hemos entrado ya en una nueva época de la historia de la Tierra? Rev. R. Acad. Cienc. Exact. Fís. Nat. 105 (1), 1-12.

Bruschi, V.M., Bonachea, J., Remondo, J., Gómez-Arozamena, J., Rivas, V., Barbieri, M. Capocchi, S, Soldati, M., Cendrero, A., 2013. Land management versus natural factors in land instability; some examples in northern Spain. Environ. Manag. 52, 398-416.

Bruschi, V.M., Bonachea, J., Remondo, J., Gómez-Arozamena, J., Rivas, V., Méndez, G. Naredo, J.M., Cendrero, A., 2012b. Analysis of geomorphic systems' response to natural and human drivers in northern Spain: implications for global geomorphic change. Geomorphology 196, 67-279.

Bujan, A., Massobrio, M., Castiglioni, M., Yánez, M., Ciallella, H., Fernández, J. Santanatoglia, O.J., Chagas, C., 2003. Soil erosion evaluation in a small basin through the use of 137Cs technique. Soil Tillage Res. 69, 127-137.

Cappuyns, V., Deweirt, V., Rousseau, S., 2015. Dredged sediments as a resource for brick production: possibilities and barriers from a consumers' perspective. Waste Manag. $38,372-380$.
Carvalho, O., Guimaraes, R., Freitas, L., Gomes-Loebmann, D., Gomes, R.A., Martins, E.R., Montgomery, D.R., 2010. Urbanization impacts upon catchment hydrology and gully development using mutli-temporal digital elevation data analysis. Earth Surf. Process. Landf. 35, 611-617.

Cavallotto, J.L., 2002. Evolución holocena de la llanura costera del margen sur del Río de la Plata. Rev. Asoc. Geol. Argent. 57 (4), 376-388

Cendrero, A., Douglas, I., 1996. Earth surface processes, materials use and urban development; project aims and methodological approach. Abstracts With Programs, GSA Annual Meeting, Denver.

Cendrero, A., Remondo, Bonachea, J., Rivas, V., Soto, J., 2006. Sensitivity of landscape evolution and geomorphic processes to direct and indirect human influence. Geogr. Fis. Geodin. Quaternaria 29 (2), 125-137.

Chiang, K.Y., Chien, K.L., Hwang, S.J., 2008. Study on the characteristics of building bricks produced from reservoir sediment. J. Hazard. Mater. 159, 499-504.

Chin, A., 2006. Urban transformation of river landscapes in a global context. Geomorphology $79,460-487$

CIRSOC 501, 2007. Reglamento argentino de estructuras de mampostería. Centro de Investigaciones de los Reglamentos Nacionales de Seguridad para las Obras Civiles (CIRSOC). Buenos Aires, Argentina, Instituto Nacional de Tecnología Industrial (INTI) (50 pp.).

Dal Sasso, P., Ottolino, M.A., Caliandro, L.P., 2012. Identification of quarries rehabilitation scenarios: a case study within the metropolitan area of Bari (Italy). Environ. Manag. $49,1174-1191$.

Dangavs, N., 2009a. Los paleoambientes cuaternarios del arroyo La Horqueta, Chascomús,provincia de Buenos Aires. Rev. Asoc. Geol. Argent. 64 (2), $249-262$.

Dangavs, N., 2009b. Paleolimnología de las lagunas periódicas (secas) Esquivel, del Medio y El Espartillar, Chascomús, Buenos Aires. IV Congreso Argentino de Cuaternario y Geomorfología, XII Congresso da Assoçiacão Brasileira de Estudos do Cuaternario y II Reunión sobre el Cuaternario de América del Sur, Actas CD, pp. 290-299.

Dangavs, N., 2009c. Estratigrafía pleistocena tardía-holocena y paleolimnología de la laguna Chis Chis, Chascomús, Buenos Aires, Argentina. IV Congreso Argentino de Cuaternario y Geomorfología, XII Congresso da Assoçiacão Brasileira de Estudos do Cuaternario y II Reunión sobre el Cuaternario de América del Sur, Actas CD, pp. 300-309.

Dangavs, N.V., 2008. Los paleoambientes cuaternarios del arroyo la Horqueta, Chascomús, provincia de Buenos Aires. Rev. Asoc. Geol. Argent. 64 (2), 249-262.

Dangavs, N.V., 2010. Geología ambiental de la laguna de las Perdices, Monte, Buenos Aires, Argentina. Vol. 1. Asociación de Universidadess Grupo Montevideo, AUGMDOMUS, pp. 67-104.

Dangavs, N.V., Reynaldi, J.M., 2008. Paleolimnología de la laguna Cerrillo del medio, Monte, provincia de Buenos Aires. Rev. Asoc. Geol. Argent. 63 (1), 29-42.

Dangavs, N.V., Merlo, D.O., Mormeneo, L.M., 2006. Geolimnología de los cuerpos lénticos de la cuenca del arroyo La Vigilancia, Chascomús, Provincia de Buenos Aires. Rev. Museo La Plata Geol. 12 (115), 1-29.

Dangavs, N.V., 1979. Presencia de dunas de arcilla fósiles en la Pampa Deprimida. Rev. Asoc. Geol. Argent. 34 (1), 31-35

Dangavs, N.V., 2005. Los ambientes acuáticos de la provincia de Buenos Aires. En: Relatorio del XVI Congreso Geológico Argentino. Capítulo XIII. La Plata.

Dangavs, N.V., Blasi, A., 2003. El Miembro Lobos de la Formación Luján: Cambio de rango de la Formación Lobos, unidad estratigráfica del Pleistoceno superior de la cuenca del río Salado de la provincia de Buenos Aires. Segundo Congreso Argentino de Cuaternario y Geomorfología. Actas, pp. 67-74 (San Migruel de Tucumán).

Dangavs, N.V., Mormeneo, M., 2012. Geolimnología de la laguna Adela, Chascomús, provincia de Buenos Aires. Revista del Museo de La Plata, Sección Geología.

Dangavs, N.V., Pierrard, L., 2013. Paleolimnología de la laguna del Monte, San Miguel del Monte, Buenos Aires, Argentina. Rev. Asoc. Geol. Argent. 70 (1), 128-143.

Dangvas, Merlo, D., 1994. Desarrollo endógeno del partido de San Vicente. Estudio geolimnológico de la cuenca del arroyo San Vicente, provincia de Buenos Aires. Comisión de Investigaciones Científicas de la provincia de Buenos Aires. Inf. Téc. (Tomos 1 y 2).

Dangvas, N.V., Blasi, A.M., 1994. Quaternary ontogeny of a pampean "laguna". Sedimentological and biological characteristics of Lobos Lake sediments Argentina. J. Paleolimnol. 10 (1), 59-62.

Dangvas, N.V., Blasi, A.M., 2002. Los depósitos de yeso intrasedimentario del arroyo del Siasgo, partidos de Monte y General Paz, provincia de Buenos Aires. Rev. Asoc. Geol. Argent. 57 (3), 315-327.

Dangvas, N.V., Merlo, D., 1997. Geología Ambiental de la laguna de Quinteros. Partidos de Chascomús y General Paz, provincia de Buenos Aires. En: Situación Ambiental de la provincia de Buenos Aire; Parte A. Recursos y rasgos naturales en la evaluación ambiental Vol. 30. Comisión de Investigaciones Científicas de la provincia de Buenos Aires, pp. 1-32

Del Río, J.L., Müller, M., Martínez Arca, J., Bó, J., Bernasconi, M.V., 2001. El desarrrollo urbano y la minería de suelos en el sudeste de la provincia de Buenos Aires, Argentina. Proceedings III Reunión de Geología Ambiental y Ordenación del Territorio y I Reunión de Geología Ambiental y Ordenación del Territorio del Área del MERCOSUR. Mar del Plata (CD format).

Dillon, A., Rabassa, J., 1985. Miembro La Chumbiada, Formación Luján (Pleistoceno, provincia de Buenos Aires): Una nueva unidad estratigráfica del valle del río Salado. Primeras Jornadas Geológicas Bonaerenses, Resúmenes, p. 27 (Tandil).

Doering, A., 1884. Estudios hidrognósticos y perforaciones artesianas en la República Argentina. Bol. Acad. Nac. Cienc. 6, 259-340.

Douglas, I., 1996. The impact of land-use changes, especially logging, shifting cultivation, mining and urbanization on sediment yields in humid tropical Southeast Asia: a review with special reference to Borneo. In: Walling, D.E., Webb, B.W. (Eds.), 
Erosion and Sediment Yield: Global and Regional Perspectives, Proceedings of the Exeter Symposium, July 1996. IAHS Publication, Wallingford, UK, pp. 463-471.

Fabbri, B., Dondi, M., 1995. Mineralogical classification of Italian clay raw materials for production of different ceramics. Proc. 5th Neubrandenburger Industriemineralsymp., pp. $45-50$

Fidalgo, F., Martínez, O.R., 1983. Algunas características geomorfológicas dentro del partido de La Plata, provincia de Buenos Aires. Rev. Asoc. Geol. Argent. 38 (2), 263-279.

Fidalgo, F., Colado, U.R., De Francesco, F.O., 1975. Sobre ingresiones marinas cuaternarias en los partidos de Castelli, Chascomús y Magdalena, provincia de Buenos Aires. Relatorio V Congreso Geológico Argentino. Vol. II, pp. 227-240.

Fidalgo, F., De Francesco, F., Colado, U., 1973. Geología superficial en las hojas Castelli, J. M. Cobo y Monasterio, provincia de Buenos Aires. Actas $5^{\circ}$ Congreso Geológico Argentino. Vol. 4, pp. 27-39.

Fidalgo, F., Riggi, J.C., Correa, H., Porro, N., 1991. Los sedimentos postpampeanos continentales en el ámbito sur bonaerense. Rev. Asoc. Geol. Argent. 46 (3-4), 239-256.

Forte, L.M., 2011. Análisis de las tendencias de variación en las tasas de actividad de los procesos geomorfológicos y de sus implicaciones para los riesgos naturales MS Thesis Universidad de Cantabria, Santander, Spain.

Forte, L.M., Hurtado, M.A., Giménez, J.E., Cabral, M.G., Crincoli, A.C., 2004. Consecuencias ambientales del desarrollo urbano y análisis de áreas fuente alternativas para la industria del ladrillo. Estudio de caso en el partido de La Plata, provincia de Buenos Aires, Argentina. Proceedings IV Congreso Uruguayo de Geología y II Reunión de Geología Ambiental y Ordenamiento del Territorio. Torre de los Profesionales, Montevideo, Uruguay (CD format).

Frank, F., Viglizzo, E., 2010. Evaluación ecológica: ejemplo de estudio en las pampas de Argentina. En: Forum de Sostenibilidad, Revista de La Cátedra Unesco Sobre Desarrollo Sostenible. Vol. 4, pp. 72-89.

Frenguelli, J., 1950. Rasgos Generales de la Morfología y la Geología de la Provincia de Buenos Aires. Revista Lemit, Serie II Vol. 33 (La Plata, Argentina).

Frenguelli, J., 1957. Neozoico. Sociedad Argentina de Estudios Geográficos (GAEA) Vol. 2. Geografía de la República Argentina, Buenos Aires, pp. 1-113.

FrePlata, 2012. Calidad ambiental de las Cuencas de los Arroyos del Gato y Pereyra Provincia de Buenos Aires, Argentina. United Nations Development Program (PNUD), Proyect ARG/09 G46. Final Report http://www.ambiente.gob.ar (latest access 18/03/2013).

Gellis, A.C., Ellevein, A., Aby, S., Pavich, M.J., Bierman, P.R., Clapp, E.M., 2004. Modern sediment yield compared to geologic rates of sediment production in a semi-arid basin; New Mexico: assessing the human impact. Earth Surf. Process. Landf. 28 (11), 1359-1372.

Giménez, J., Hurtado, M., Cabral, M., da Silva, M., 1992. Estudio de suelos del partido de La Plata. Facultad de Ciencias Naturales y Museo, Consejo Federal de Inversiones. Technical Report

Giménez, J.E., Salerno, M.I., Hurtado, M.A., 2002. Rehabilitation of surfaced soils by afforestation in La Plata county, Argentina. Land Degrad. Dev. 13, 69-77.

Gupta, S., Narayan, R., 2010. Brick kiln industry in long-term impacts biomass and diversity structure of plant communities. Curr. Sci. 99 (1), 72-79.

Haack, B.N., Khatiwada, G., 2007. Rice and Bricks: environmental issues and mapping of the unusual crop rotation pattern in the Kathmandu Valley, Nepal. Environ. Manag. $39,774-782$.

Hooke, R.L., 1994. On the efficacy of humans as geomorphic agents. GSA Today 4 (9), 224-225.

Hurtado, M., Forte, L.M., Bruschi, V., Bonachea, J., Rivas, V., Gómez-Arozamena, J., DantasFerreira, M., Remondo, J., González, A., Díaz de Terán, J.R., Salas, L., Cendrero, A., 2012. The geomorphic dimension of global change; risks and opportunities. In: González, A. (Ed.), Avances de la Geomorfología en España. SGE-Publican, Madrid, pp. 18-23.

Hurtado, M., Giménez, J., Cabral, M., 2006. Estudio Ambiental del Partido de La Plata; Aportes al Ordenamiento Territorial. Consejo Federal de Inversiones, Municipalidad de La Plata (Municipalidad de La Plata, La Plata).

Hurtado, M., Giménez, J., Cabral, M., da Silva, M., Camilion, C., Forte, L., Sánchez, C., Boff, L., Crincoli, A., Muntz, D., Lucesoli, H., Gebard, J., Martínez, O., 2004. Estudio de Suelos del Partido de La Plata. Consejo Federal de Inversiones. Technical Report.

Hurtado, M.A., 2015. Desarrollo de herramientas para el análisis, evaluación y gestión sostenible del territorio y de sus recursos. Aplicación en el Conurbano Bonaerense, provincia de Buenos Aires, Argentina PhD Thesis University of Cantabria, Santander, Spain.

Hurtado, M.A., Forte, L.M., Muntz, D., 2008. Pérdida de Suelos Por Actividades Urbanas Directas e Indirectas. Proceedings XXI Congreso Argentino de la Ciencia del Suelo. Semiárido: Un desafío para la Ciencia del Suelo, Potrero de Funes, San Luis, Argentina (CD format).

INTA, 1990. Atlas de Suelos de la República Argentina, Secretaría de Agricultura, Ganadería y Pesca, Proyecto PNUD ARG. 85/019. Instituto de Tecnología Agropecuaria, Centro de Investigaciones de Recursos Naturales. Buenos Aires.

INTI, 2007. Reglamento argentino de estructuras de mampostería CIRSOC 501. Instituto Nacional de Tecnología Industrialhttp://www.inti.gob.ar/.

IRAM. http://www.iram.org.ar/

Iriondo, M., 1999. Climatic changes in the South American plains: record of a continentalscale oscillation. Quat. Int. 57/58, 93-122.

Iriondo, M., 2010. Geología del cuaternario en la Argentina. Grupo de Estudios del Cuaternario. Museo Provincial de Ciencias Naturales Florentino Ameghino, Santa Fé.

Iriondo, M., García, N., 1993. Climatic variations in the Argentine plains during the last 18,000 years. Palaeogeogr. Palaeoclimatol. Palaeoecol. 101, 209-220.

Iriondo, M., Kröhling, D., 1995. El sistema eólico pampeano. Comunicaciones Museo Provincial de Ciencias Naturales. Vol. 5 (1), pp. 1-68.
Jordan, G., 2009. Sustainable mineral resources management: from regional mineral resources exploration to spatial contamination risk assessment of mining. Environ. Geol. 58, 153-169.

Judson, S., 1983. In: Tank, R.W. (Ed.), Erosion of the Land, What's Happening to Our Continents?Environ. Geol.Oxford Univ. Press, New York, pp. 184-197.

Kesel, R.H., Yodis, E.G., McCraw, D.J., 1992. An approximation of the sediment budget of the lower Mississippi River prior to major human modification. Earth Surf. Process. Landf. 17, 711-722.

Kilmer, V.J., Alexander, L.T., 1949. Methods for making mechanical analyses of soils. Soil Sci. $68,15-24$

Klingebiel, A.A., Montgomery, P.H., 1961. Land Capability Classification, Agriculture Handbook No. 210. Soil Conservation Service, Department of Agriculture, Washington DC.

Knox, J.C., 2006. Floodplain sedimentation in the Upper Mississippi Valley: natural versus human accelerated. Geomorphology 79, 286-310.

Kraemer, F., Chagas, C., Marré, G., Palacín, E., Santanatoglia, O., 2013. Cattle production displacement by annual cropping in a basin belonging to the rolling pampa region. Effects on runoff and soil erosion. Cienc. Suelo 31 (1), 83-92.

Lal, R., 1997. Degradation and resilience of soils. Philos. Trans. R. Soc. 352, 997-1010.

Mbumbia, L., Mertens de Wilmars, A., Tirlocq, J., 2000. Performance characteristics of lateritic soil bricks fired at low temperatures: a case study of Cameroon. Constr. Build. Mater. 14, 121-131.

Meyer, I., Wagner, S., 2009، "The Little Ice Age in Southern South America: proxy and model based evidence".Past climate variability in South America and surrounding regions. Dev. Paleoenviron. Res. 14, 395-397.

Mezencevova, A., Yeboah, N.N., Burns, S.E., Kahn, L.F., Kurtis, K.E., 2012. Utilization of Savannah Harbor river sediment as the primary raw material in production of fired brick. J. Environ. Manag. 113, 128-136.

Michelena, R.O., 2014. Personal communication.

Michelena, R.O., Irurtia, C.B., Mon, N.. Pittaluga, A., Vavruska, F. 1991. Degradación de Suelos en el norte de la Región Pampeana. Instituto Nacional de Tecnología Agropecuaria (INTA). Publicación Técnica no. 6.

Michelena, R.O., Irurtia, C.B., Pittaluga, A., Vavruska, F., de Sardi, M.E.B., 1988 Degradacción de los suelos en el sector norte de la pampa ondulada. Rev. Asoc. Argentina Cienc. Suelo 6 (1), 60-66.

Milliman, J.D., Farnsworth, K.L., 2011. River Discharge to the Coastal Ocean. A Globa Synthesis. Cambridge Univ. Press, New York.

Ngon Ngon, G.F., Yongue-Fouateu, R., Bitom, D.L., Bilong, P., 2009. A geological study of clayey laterite and clayey hydromorphic material of the region of Yaoundé (Cameroon): a prerequisite for local material promotion. J. Afr. Earth Sci. 55, 69-78.

Nzeukou, A.N., Kamgang, V.K., Medjo, R.E., Melo, U.C., Njoya, A., Lemougna, P.N., Fagel, N. 2013. Industrial potentiality of alluvial clays deposits from Cameroon: influence of lateritic clayey admixture for fired Bricks production. J. Miner. Mater. Charact. Eng. $1,236-244$.

Pereyra, F.X., 2004. Geología urbana del área metropolitana bonaerense y su influencia en la problemática ambiental. Rev. Asoc. Geol. Argent. 59 (3), 394-410.

Pereyra, F.X., Rimoldi, E.H., 2003. Geological and environmental aspects of the development of megacities: the case of Buenos Aires metropolitan area (AMBA), Argentina. Bull. Eng. Geol. Environ. 62, 341-351.

Phippen, S.J., Wohl, E., 2003. An assessment of land use and other factors affecting sediment loads in the Rio Puerco watershed, New Mexico. Geomorphology 52, 269-287.

Ramos-Scharrón, C.E., Mac Donald, L.H., 2005. Measurement and prediction of sediment production from unpaved roads, St John, US Virgin Islands. Earth Surf. Process. Landf. 30, 1283-1304.

Riggi, J., Fidalgo, F., Martínez, O., Porro, N., 1986. Geología de los “Sedimentos Pampeanos” en el partido de La Plata. Rev. Asoc. Geol. Argent. 41 (3-4), 316-333.

Rivas, V., Cendrero, A., Hurtado, M., Cabral, M., Giménez, J., Forte, L., del Río, L., Cantú, M. Becker, A., 2006. Geomorphic consequences of urban development and mining activities; an analysis of study areas in Spain and Argentina. Geomorphology 73 (3-4), 185-206.

Samara, M., Lafhaj, Z., Chapiseau, Ch., 2009. Valorization of stabilized river sediments in fired clay bricks: factory scale experiment. J. Hazard. Mater. 163, 701-710.

Santhosh, V., Padmalal, D., Baijulal, B., Maya, K., 2013. Brick and tile clay mining from the paddy lands of Central Kerala (southwest coast of India) and emerging environmental issues. Environ. Earth Sci. 68, 2111-2121.

Shepard, F.P., 1954. Nomenclature based on sand-silt-clay ratios. J. Sediment. Petrol. 24 $151-158$.

Singh, A.L., Asgher, M.S., 2005. Impact of brick kilns on land use/land cover changes around Aligarh City, India. Habitat Int. 29, 591-602.

Steffen, W., Broadgate, W., Deutsch, L., Gaffney, O., Ludwig, C., 2015. The trajectory of the Anthropocene: the great acceleration. Anthropocene Rev. 2 (1), 81-98.

Steffen, W., Grinevald, J., Crutzen, P., McNeill, J., 2011. The Anthropocene: conceptual and historical perspectives. Phil. Trans. R. Soc. A 369, 842-867.

Steffen, W., Sanderson, A., Tyson, P.D., Jäger, J., Matson, P.A., Moore III, B., Oldfield, F., Richardson, K., Schellnhuber, H.J., Turner, B.L., Wasson, R.J., 2004. Global Change and the Earth System: A Planet Under Pressure. Springer-Verlag, Berlin Heidelberg, New York.

Subba Rao, N., Prathap Reddy, R., 2004. Geoenvironmental appraisal in a developing urban area. Environ. Geol. 47, 20-29.

Syvitski, J.P.M., Kettner, A., 2011. Sediment flux and the Anthropocene. Philos. Trans. R. Soc. A Math. Phys. Eng. Sci. 369, 957-975.

Syvitski, J.P.M., Milliman, J.D., 2007. Geology, geography, and humans battle for dominance over the delivery of fluvial sediment to the Coastal Ocean. J. Geol. 115, 1-19.

Syvitski, J.P.M., Vörösmarty, C.J., Kettner, A.J., Green, P., 2005. Impacts of humans on the flux of terrestrial sediment to the global coastal ocean. Science 308, 376-380.

Tarolli, P., Sofia, G., 2016. Human topographic signatures and derived geomorphic processes across landscapes. Geomorphology 255, 140-161. 
Thompson, L.G., Mosley-Thompson, E., Davis, M.E., Lin, P.N., Henderson, K., Mashiotta, T.A., 2003. "Tropical Glacier and Ice Core evidence of climate change on annual to millennial time Scales".Climate variability and change in high elevation regions: past, present \& future. Adv. Glob. Chang. Res. 15, 137-138.

Valentín, J., 1898. Bosquejo geológico de la Argentina. Segundo Censo Nacional 1895 Parte Geol. 61-109 (Buenos Aires).

Villalba, R., 1990. Climatic fluctuations in Northern Patagonian during the last 1000 years as inferred from tree-rings records. Quat. Res. 34 (3), 346-360.

Villalba, R., 1994. Tree-ring and glacial evidence for the medieval warm epoch and the Little Ice Age in southern South America. Clim. Chang. 26 (2-3), 183-197.

Walling, D.E., 2000. Linking land use, erosion and sediment yields in river basins. Hydrobiologia 410, 223-240.

Walling, D.E., 2006. Human impact on land-ocean sediment transfer by the world's rivers. Geomorphology 79, 192-216.

Waters, Colin N. Jan Zalasiewicz, Colin Summerhayes, Anthony D. Barnosky, Clément Poirier, Agnieszka Gałuszka, Alejandro Cearreta, Matt Edgeworth, Erle C. Ellis, Michae Ellis, Catherine Jeandel, Reinhold Leinfelder, J. R. McNeill, Daniel de B. Richter, Will Steffen, James Syvitski, Davor Vidas, Michael Wagreich, Mark Williams, An Zhisheng Jacques Grinevald, Eric Odada, Naomi Oreskes, Alexander P. Wolfe. 2016. The Anthropocene is functionally and stratigraphically distinct from the Holocene. Science, Vol 351, Issue 6269:137-147.
Wilkinson, B.H., McElroy, B.J., 2007. The impact of humans on continental erosion and sedimentation. GSA Bull. 1 (2), 140-156.

Winkler, H.G.F., 1954. Bedeutung der KorngriSssenverteilung und des Mineralbestandes von Tonen fiir die Herstellung grobkeramischer Erzeugnisse. Ber. Dtsch. Keram. Ges. 31 (10), 337-343.

Yadav, S.K., 2003. Remote sensing based management of degraded soil due to brick industry for sustainable development - a case study. J. Hum. Ecol. 14 (6), 451-455.

Yang, S.L., Zhi, Z., Zhao, H.Y., Li, P., Dai, S.B., Gao, A., 2004. Effects of human activities on the Yangtze River suspended sediment flux into the estuary in the last century. Hydrol. Earth Syst. Sci. 8, 1210-1216.

Zhang, M., Fang, L., 2007. Effect of tillage, fertilizer and green manure cropping on soil quality at an abandoned brick making site. Soil Tillage Res. 93, 87-93.

Ziegler, A.D., Sutherland, R.A., Giambelluca, T.W., 2000. Runoff generation and sediment production on unpaved roads, footpaths and agricultural land surfaces in northern Thailand. Earth Surf. Process. Landf. 25, 519-534.

Zuquette, L.V., Pejon, O.J., Dantas-Ferreira, M., Palma, J.B., 2009. Environmental degradation related to mining, urbanization and pollutant sources: Poços de Caldas, Brazil. Bull. Eng. Geol. Environ. 68, 317-329. 